\title{
Novel Bifunctional Acylase from Actinoplanes utahensis: A Versatile Enzyme to Synthesize Antimicrobial Compounds and Use in Quorum Quenching Processes
}

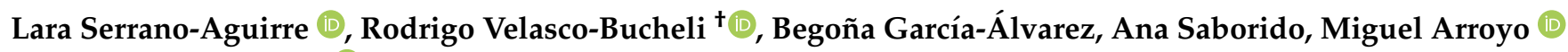 \\ and Isabel de la Mata *(D) \\ Department of Biochemistry and Molecular Biology, Faculty of Biology, Universidad Complutense de \\ Madrid (UCM), José Antonio Nováis 12, E-28040 Madrid, Spain; larase01@ucm.es (L.S.-A.); \\ rvelasc@unal.edu.co (R.V.-B.); begoga01@ucm.es (B.G.-Á.); asaborid@ucm.es (A.S.); marroyos@ucm.es (M.A.) \\ * Correspondence: idlmata@ucm.es; Tel.: +34-913944150 \\ † Present address: Roche Diagnostics GmbH, 82377 Penzberg, Germany.
}

check for updates

Citation: Serrano-Aguirre, L.; Velasco-Bucheli, R.; García-Álvarez, B.; Saborido, A.; Arroyo, M.; de la Mata, I. Novel Bifunctional Acylase from Actinoplanes utahensis: A Versatile Enzyme to Synthesize Antimicrobial Compounds and Use in Quorum Quenching Processes. Antibiotics 2021, 10, 922. https:// doi.org/10.3390/antibiotics10080922

Academic Editor: Martina Hrast

Received: 5 July 2021

Accepted: 27 July 2021

Published: 29 July 2021

Publisher's Note: MDPI stays neutral with regard to jurisdictional claims in published maps and institutional affiliations.

Copyright: (c) 2021 by the authors. Licensee MDPI, Basel, Switzerland. This article is an open access article distributed under the terms and conditions of the Creative Commons Attribution (CC BY) license (https:/ / creativecommons.org/licenses/by/ $4.0 /)$.

\begin{abstract}
Many intercellular communication processes, known as quorum sensing (QS), are regulated by the autoinducers $N$-acyl-L-homoserine lactones (AHLs) in Gram-negative bacteria. The inactivation of these QS processes using different quorum quenching (QQ) strategies, such as enzymatic degradation of the autoinducers or the receptor blocking with non-active analogs, could be the basis for the development of new antimicrobials. This study details the heterologous expression, purification, and characterization of a novel $N$-acylhomoserine lactone acylase from Actinoplanes utahensis NRRL 12052 (AuAHLA), which can hydrolyze different natural penicillins and $N$-acyl-homoserine lactones (with or without 3-oxo substitution), as well as synthesize them. Kinetic parameters for the hydrolysis of a broad range of substrates have shown that $A u$ AHLA prefers penicillin $\mathrm{V}$, followed by $\mathrm{C}_{12}$-HSL. In addition, AuAHLA inhibits the production of violacein by Chromobacterium violaceum CV026, confirming its potential use as a QQ agent. Noteworthy, AuAHLA is also able to efficiently synthesize penicillin $\mathrm{V}$, besides natural AHLs and phenoxyacetyl-homoserine lactone (POHL), a nonnatural analog of AHLs that could be used to block QS receptors and inhibit signal of autoinducers, being the first reported AHL acylase capable of synthesizing AHLs.
\end{abstract}

Keywords: $N$-acyl-homoserine lactone; $N$-acyl-homoserine lactone acylase; penicillin acylase; Ntnhydrolase; quorum sensing; quorum quenching; Actinoplanes utahensis

\section{Introduction}

$N$-acyl-L-homoserine lactones (AHLs) are small signal molecules involved in intercellular communication processes, known as quorum sensing (QS), in Gram-negative bacteria. QS allows a bacterial community to synchronize the expression of a set of target genes in order to respond to environmental changes in a density-dependent manner [1]. Several biological functions, such as secretion of virulence factors and biofilm formation, are regulated by this mechanism in many pathogenic microorganisms [2-4]. AHLs are composed of the homoserine lactone ring (HSL) and an acyl chain with a different number of carbons, saturation, or side-chain substitution [5]. Quorum quenching (QQ) processes consist of the interference of QS by inhibition of the biosynthesis or detection of signal molecules or by enzymatic modification or degradation of the autoinducers [6]. Among QQ enzymes, the main groups of AHL-degrading or modifying enzymes are lactonases, which catalyze the hydrolysis of the lactone ring; acylases, which catalyze the hydrolysis of the amide bond to form the homoserine lactone ring (HSL) and the corresponding fatty acid; and oxidoreductases, which reduce the carbonyl to hydroxyl [7-9]. QQ enzymes could be used for biotechnological applications such as antivirulence tool in the control and treatment of bacterial infections [10] and decreasing of biofouling in membrane bioreactors [11-13]. 
Another QQ approach consists in AHLs analogs that form non-active signal-receptor complexes. Multiple studies have investigated this strategy, including modified AHLs, non-natural AHLs and non-AHL scaffold compounds [6,14].

Fatty acids and HSL released by AHL acylases cannot form a functional QS signal spontaneously, and they can be used as carbon and nitrogen source [15]. Most of the described and characterized AHL acylases belong to the N-terminal nucleophile (Ntn) hydrolase superfamily with an $\alpha \beta \beta \alpha$ fold and a nucleophilic catalytic residue in the Nterminal [16]. These enzymes are synthesized as a single polypeptide chain with a signal peptide, an $\alpha$-subunit, a spacer peptide, and a $\beta$-subunit [17]. The $\alpha$ - and $\beta$-subunits are about 20 and $60 \mathrm{kDa}$, respectively [18]. Other characteristic enzymes of this superfamily are $\beta$-lactam acylases such as penicillin acylases, having reported AHL acylase activity for some of them $[19,20]$. Penicillin acylases are commonly used for the synthesis of $\beta$ lactam antibiotics such as semisynthetic penicillins, by deacylation of natural penicillins and acylation of 6-aminopenicillanic acid (6-APA) using non-natural side chains [21,22]. However, none acylase able to synthesize AHLs has yet been described.

In the present study, we report the heterologous expression and characterization of a novel bifunctional acylase from Actinoplanes utahensis NRRL 12052 (AuAHLA) and its hydrolytic activity against different natural penicillins and $N$-acyl-homoserine lactones, evaluating its possible role as a QQ agent. More interesting, we demonstrate its capacity to carry out the enzymatic synthesis of penicillin $\mathrm{V}$, as well as natural AHLs and non-natural analogs of AHLs that could be used in QQ processes, being the first example of AHLs enzymatic synthesis catalyzed by an acylase.

\section{Results}

2.1. Identification of the Putative ahla Gene in the Genome of Actinoplanes utahensis NRRL 12052

The presence of the putative ahla gene was detected in the draft genome of Actinoplanes utahensis NRRL 12052 [23]. This gene, as well as the aac gene, which encodes for the aculeacin A acylase from $A$. utahensis (AuAAC) [24], was located within contig 8 and related to nonribosomal peptide synthetases (NRPS) and siderophores biosynthesis based on antiSMASH analysis [25]. In particular, ahla gene was identified within cluster 3 and was related to gobichelin biosynthesis, while aac gene was identified within cluster 5 and was related to laspartomycin biosynthesis (Figure 1).

The amino acid sequence of this putative AuAHLA deduced from the ahla gene has 808 residues, with a predicted signal peptide of 33 amino acids, according to SignalP predictor [26] and $\alpha$ - and $\beta$-subunits of 21.6 and $59.8 \mathrm{kDa}$, respectively, according to ExPASy ProtParam tool [27]. AuAHLA keeps $44 \%$ of identity with $A u$ AAC [24,28], 51\% with penicillin V acylase from Streptomyces lavendulae (SlPVA) [29], 48\% with penicillin V acylase from Streptomyces mobaraensis (SmPVA) [30], 50\% with acylhomoserine lactone acylase from Streptomyces sp. M664 (AhlM) [31], and 50\% with cyclic lipopeptide acylase from Streptomyces FERM-BP5809 (SsCLA) [32] (Supplementary Material, Figure S1). Moreover, sequence alignment analysis by COBALT [33] using AuAHLA, AuAAC, SlPVA, and other 174 acylases indicated the presence of conserved essential amino acids involved in catalysis and substrate binding (Supplementary Material, Table S1). 


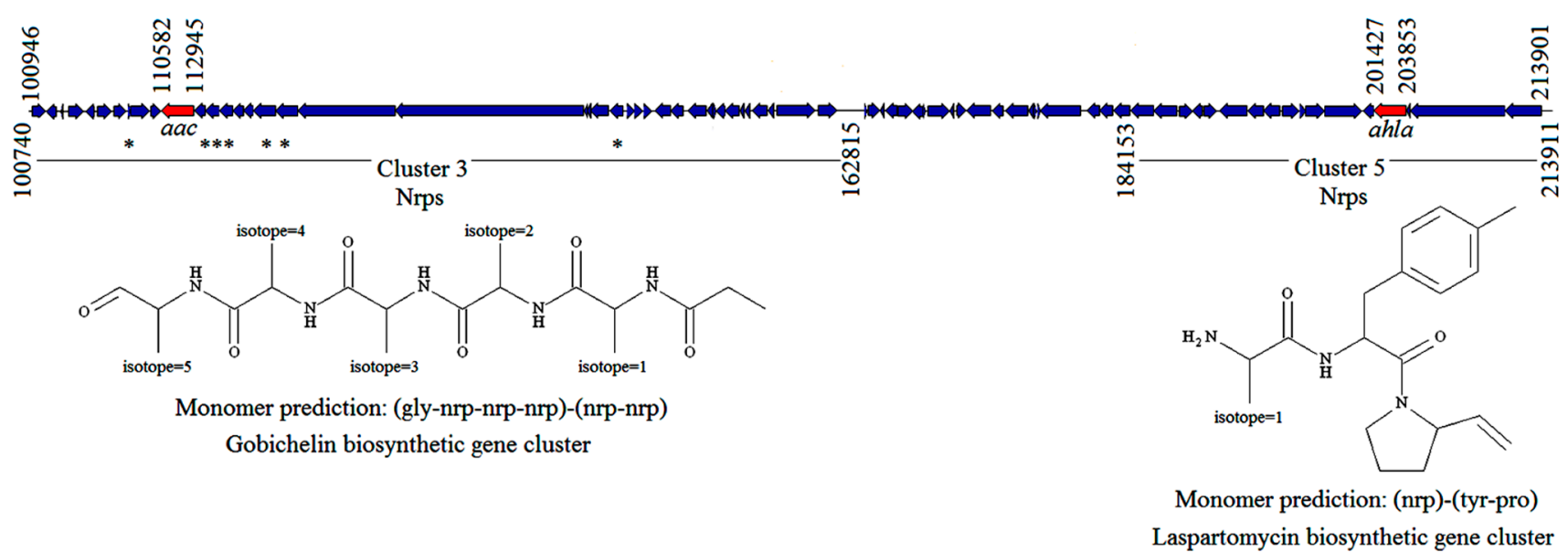

Figure 1. Clusters 3 and 5 within the contig 8-containing aac and ahla genes (highlighted in red), and rough prediction of core scaffolds produced by those clusters based on assumed PKS/NRPS collinearity without considering tailoring reactions. Genes highlighted with asterisks are related to ABC-transporter systems. The predicted gene clusters contain the domain annotations and the prediction of putative core structures. In both cases, the role of these acylases seems to be relevant in the synthesis of nonribosomal peptides.

\subsection{Heterologous Expression and Purification of AuAHLA}

The putative ahla gene was amplified by PCR, cloned in the pENV19, and the recombinant strain Rhodococcus pENV19ahla was obtained as described in the Materials and Methods section. After $72 \mathrm{~h}$ at $30^{\circ} \mathrm{C}$, penicillin acylase activity was detected in the recombinant strain culture supernatants, indicating that the signal peptide of native $A u$ AHLA was correctly recognized by Rhodococcus. Recombinant AuAHLA was purified 19-fold from the cell-free broth by only one chromatographic step followed by an ultrafiltration step (Supplementary Material, Table S2), being a considerably fast procedure. The SDSPAGE analysis of purified AuAHLA (Figure 2A) showed that the enzyme is a heterodimer composed of two subunits, and the molecular mass determined by MALDI-TOF for $\alpha$ and $\beta$-subunits were 20 and $66.4 \mathrm{kDa}$, respectively (Supplementary Material, Figure S2A). Moreover, the identity of $\alpha$ - and $\beta$-subunits detected in the SDS-PAGE was confirmed by peptide mass fingerprinting of each band (Supplementary Material, Figure S2B). The $\mathrm{N}$-terminal amino acid sequences determined for $\alpha$ - and $\beta$-subunits were (G)ADRPHAVVR and SNAVAAGRDG, respectively. These results confirmed that Rhodococcus produces the mature enzyme extracellularly, as well as the presence of a signal peptide of 34-35 amino acids.

(A)

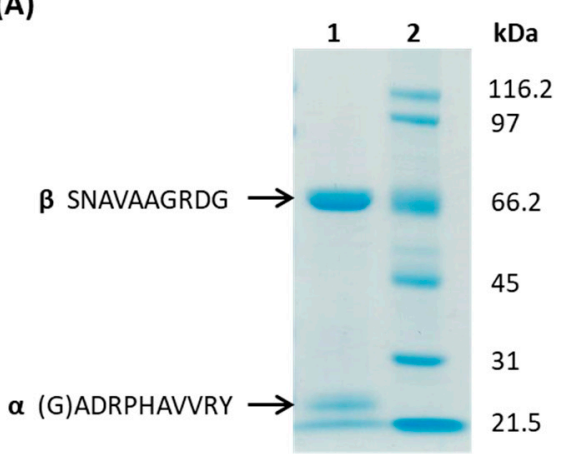

(B)

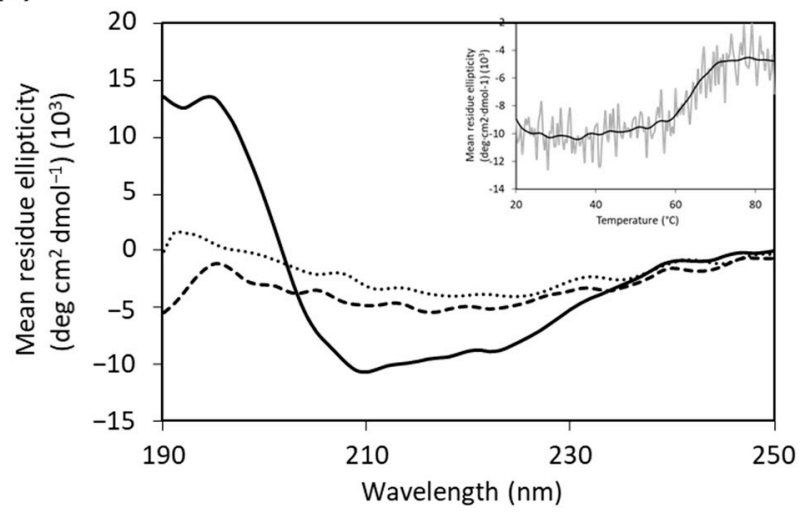

Figure 2. (A) SDS-PAGE analysis of purified AuAHLA produced by the recombinant strain Rhodococcus pENV19ahla. Lane 1, purified $A u A H L A$; lane 2, standard molecular mass markers. (B) Far-UV CD spectra of $A u A H L A 0.07 \mathrm{mg} / \mathrm{mL}$ at $20{ }^{\circ} \mathrm{C}$ (solid line), $85^{\circ} \mathrm{C}$ (dashed line) and $20^{\circ} \mathrm{C}$ after thermal unfolding (dotted line). Inset shows thermal unfolding of $A u A H L A$ at $208 \mathrm{~nm}$ between 20 and $85^{\circ} \mathrm{C}$. 


\subsection{Characterization of Recombinant AuAHLA}

After its purification, the recombinant $A u$ AHLA was structurally and functionally characterized. First, its molar extinction coefficient was determined by the method of Edelhoch [34], being $\varepsilon^{280}=111,302 \mathrm{M}^{-1} \mathrm{~cm}^{-1}$. The homogeneity and oligomeric state of $A u$ AHLA was studied by analytical ultracentrifugation (Supplementary Material, Figure S2D). Sedimentation coefficients were determined from the analysis of sedimentation velocity experiments, and the presence of the main species with an $S$ value of 4.8 was observed. This value is compatible with the behavior of a globular protein with a molecular weight of $66.2 \mathrm{kDa}$, being a smaller size than the molecular weight determined by MALDI-TOF analysis for $A u$ AHLA. This result revealed that this protein probably shows a spheroid oblate-shape with different hydrodynamic properties [35], as previously observed for SlPVA and $A u \mathrm{AAC}$ (unpublished data).

The secondary structure of $A u$ AHLA was analyzed by CD spectroscopy in the farUV region (Figure 2B). AuAHLA contains 31\% $\alpha$-helix, 18.7\% $\beta$-sheet, $17.4 \% \beta$-turn, and $33.7 \%$ random coil structure. Moreover, CD thermal denaturation revealed that $A u$ AHLA was thermostable, showing a melting temperature $\left(\mathrm{T}_{\mathrm{m}}\right)$ of $64^{\circ} \mathrm{C}$ (Figure $2 \mathrm{~B}$, inset). The predicted 3D structure bioinformatic model of $A u$ AHLA and its putative catalytic amino acids ( $\beta$ Ser1, $\beta$ His23, $\beta$ Val70, and $\beta$ Asn274) are shown in Figure 3A. In addition, the shape of purified $A u$ AHLA was analyzed by negative-stain electron microscopy (Figure $3 \mathrm{~B}$ ), revealing the presence of monodisperse and uniform molecules with a diameter of about $8 \mathrm{~nm}$, consistent with the size of AuAHLA heterodimers, which probably correspond to a top view of the enzyme (Figure 3A, left). These particles present a hole in the middle of them, where catalytic amino acids are presumably located, and substrate could be fitted.
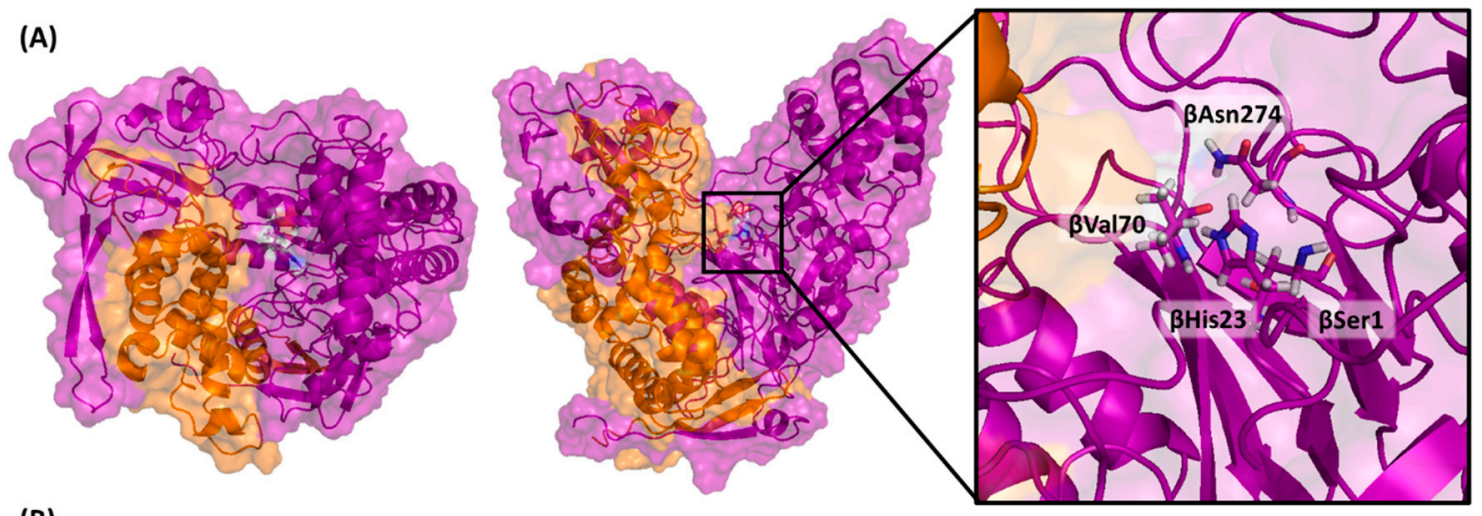

(B)
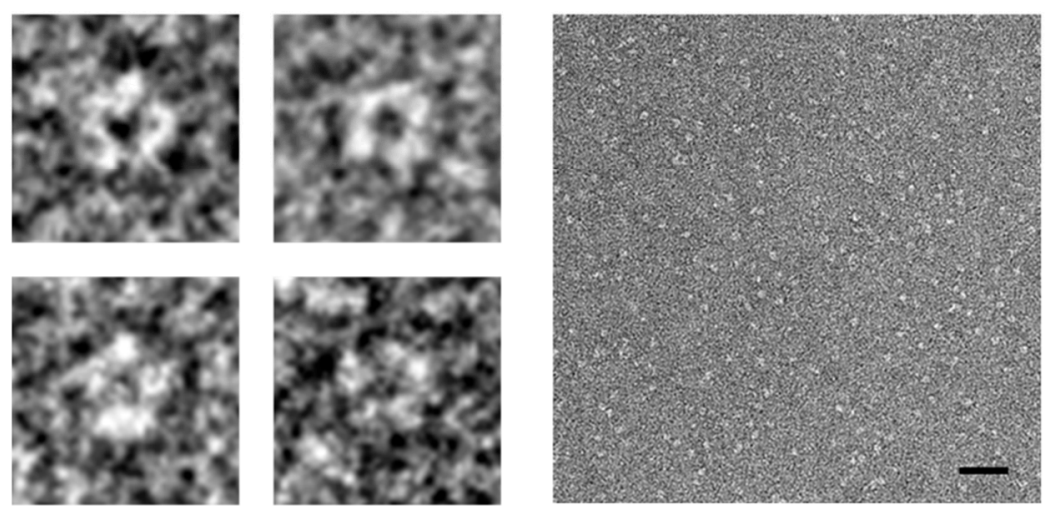

Figure 3. Tridimensional structure analysis of AuAHLA. (A) Predicted 3D heterodimeric structure model of $A u$ AHLA, showing $\alpha$-subunit in orange and $\beta$-subunit in purple. Top view, side view, and putative active-site catalytic amino acids ( $\beta$ Ser1, $\beta$ His23, $\beta$ Val70, and $\beta$ Asn274) are shown. (B) Electron microscopy micrographs of negatively stained AuAHLA. A nominal magnification of 50,000, scale bar $50 \mathrm{~nm}$. Left, representative $A u$ AHLA particles with an approximate diameter of $8 \mathrm{~nm}$, and right, image of monodisperse and uniform $A u$ AHLA sample. 
Furthermore, the effect of temperature, $\mathrm{pH}$, and organic co-solvents on the acylase activity of $A u$ AHLA was studied. The enzyme was quite stable at temperatures below $50{ }^{\circ} \mathrm{C}$ and at a wide $\mathrm{pH}$ range, between 6 and 11, and it showed maximum activity at $55^{\circ} \mathrm{C}$ and $\mathrm{pH}$ values between 7.5 and 9.5 (Figure 4A,B). Therefore, the optimum reaction temperature and $\mathrm{pH}$ for further experiments were set at $45^{\circ} \mathrm{C}$ and $\mathrm{pH}$ 8.0. The activation energy was also calculated using the Arrhenius equation, being $53.3 \mathrm{~kJ} \mathrm{~mol}^{-1}$. Moreover, the activity of $\mathrm{AuAHLA}$ was not affected by the presence of $\mathrm{NaCl}$ at concentrations below $1 \mathrm{M}$ (data not shown).

Acylase activity of $A u$ AHLA was also assayed in the presence of different concentrations of organic co-solvents (Figure 4C-E). The addition of aprotic polar solvents resulted in a decrease in acylase activity at around $80 \%$ at $15 \%(v / v)$ DMSO and $20 \%(v / v)$ acetone (Figure $4 \mathrm{C}$ ), while in the presence of alcohols and polyols, acylase activity was quite stable until 15\% $(v / v)$ ethanol and 2-propanol and 25\% $(v / v)$ methanol (Figure 4D). The enzyme kept its acylase activity until 25\% (v/v) glycerol and ethylene glycol (EG), while its activity decreased at $60 \%$ at the same concentration of diethylene glycol (DEG) (Figure 4E).

(A)

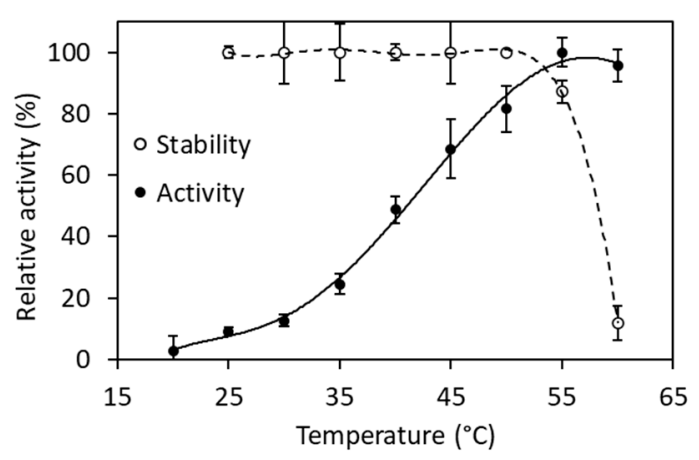

(c)

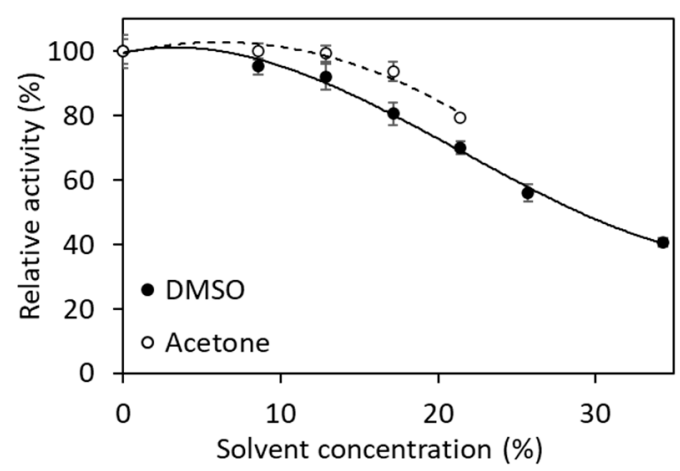

(B)

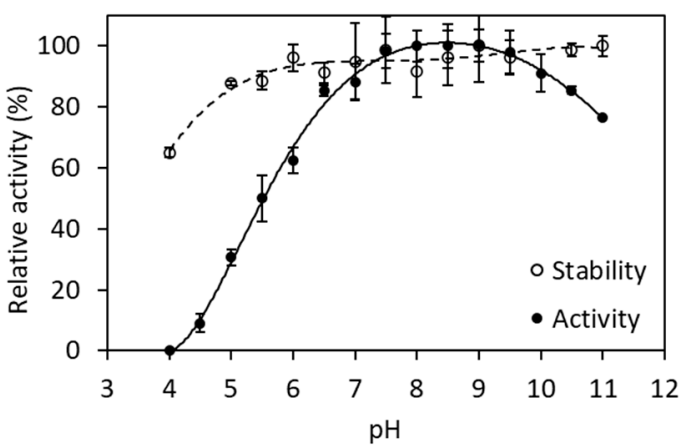

(D)

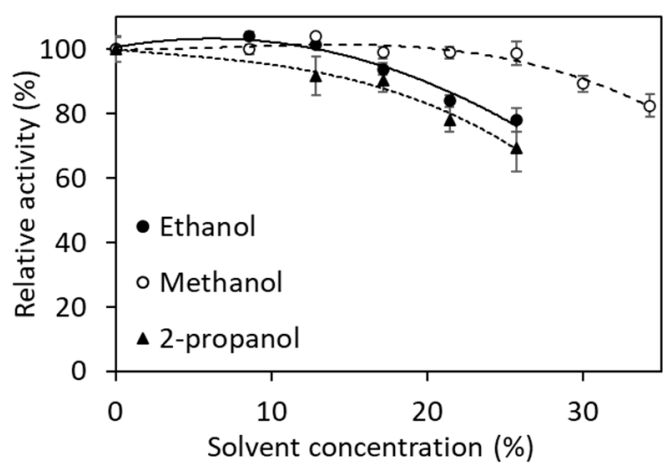

(E)

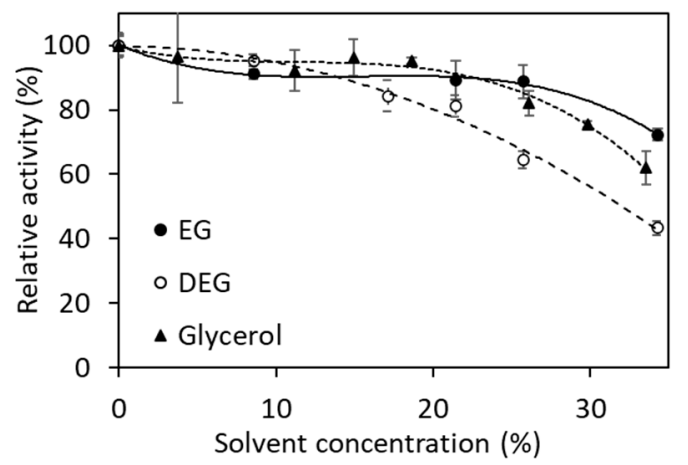

Figure 4. Biochemical characterization of AuAHLA. Effect of temperature (A) and $\mathrm{pH}$ (B) on AuAHLA activity and stability. Effect of organic co-solvents on AuAHLA activity: aprotic polar solvents (C), alcohols (D), and glycerol and glycols (E). 


\subsection{Kinetic Parameters of AuAHLA for the Hydrolysis of Different Substrates}

Substrate specificity of $A u$ AHLA was determined by calculating the kinetic parameters for the hydrolysis of several penicillins and enantiopure $\mathrm{N}$-acyl-L-homoserine lactones (Table 1) using the spectrofluorimetric assay described in the Materials and Methods section. AuAHLA was able to hydrolyze different penicillins, being penicillin $\mathrm{V}$ the best substrate, followed by penicillin dihydroF. In the case of aliphatic AHLs, AuAHLA showed the highest catalytic efficiency with $\mathrm{C}_{12}-\mathrm{HSL}$, followed by $\mathrm{C}_{10}$-HSL. When 3-oxo-AHLs were used as substrate, the catalytic efficiency is drastically decreased with respect to the homologous AHLs with aliphatic acyl chains. These results suggest that the 3-oxo group has a negative impact on enzyme-substrate interaction. Moreover, kinetic parameters for $\mathrm{C}_{4}$-HSL and 3-oxo- $\mathrm{C}_{6}$-HSL could not be determined, and for 3-oxo- $\mathrm{C}_{8}-\mathrm{HSL}$, the catalytic efficiency was poor. Acylase activity of $A u$ AHLA was also tested using aculeacin A and caspofungin as substrates, but no hydrolysis was observed (data not shown).

Table 1. Kinetic parameters of AuAHLA using different natural penicillins and AHLs as substrate.

\begin{tabular}{|c|c|c|c|}
\hline Substrate & $K m(\mathbf{m M})$ & kcat $\left(\mathrm{s}^{-1}\right)$ & $k c a t / K m\left(\mathrm{mM}^{-1} \mathrm{~s}^{-1}\right)$ \\
\hline Penicillin V & $0.472 \pm 0.05$ & $106.34 \pm 2.84$ & 239.3 \\
\hline Penicillin dihidroF & $0.199 \pm 0.02$ & $9.15 \pm 0.28$ & 48.8 \\
\hline Penicillin K & $0.675 \pm 0.19$ & $2.33 \pm 0.23$ & 3.66 \\
\hline Penicillin G & $1.21 \pm 0.30$ & $2.71 \pm 0.18$ & 2.39 \\
\hline $\mathrm{C}_{4}$-HSL & ND & ND & ND \\
\hline $\mathrm{C}_{6}-\mathrm{HSL}$ & $2.25 \pm 0.50$ & $6.07 \pm 0.69$ & 2.87 \\
\hline $\mathrm{C}_{8}$-HSL & $0.860 \pm 0.15$ & $3.52 \pm 0.29$ & 4.35 \\
\hline $\mathrm{C}_{10}-\mathrm{HSL}$ & $0.084 \pm 0.021$ & $2.59 \pm 0.23$ & 32.7 \\
\hline $\mathrm{C}_{12}$-HSL & $0.008 \pm 0.002$ & $0.75 \pm 0.045$ & 99.5 \\
\hline 3-oxo- $\mathrm{C}_{6}$-HSL & ND & ND & ND \\
\hline 3-oxo-C 8 -HSL & $1.04 \pm 0.42$ & $0.19 \pm 0.028$ & 0.20 \\
\hline 3-oxo- $\mathrm{C}_{10}$-HSL & $0.238 \pm 0.086$ & $0.50 \pm 0.097$ & 2.22 \\
\hline 3-oxo- $\mathrm{C}_{12}$-HSL & $0.092 \pm 0.021$ & $0.53 \pm 0.039$ & 6.11 \\
\hline
\end{tabular}

Reaction conditions: $45^{\circ} \mathrm{C}, 0.2 \mathrm{M}$ potassium phosphate $\mathrm{pH} 8.0$ buffer, $0.18 \mu \mathrm{g}$ AuAHLA and $20 \%(v / v)$ DMSO in the case of AHLs. ND: no activity detected.

\subsection{Synthetic Activity of AuAHLA}

In addition to the analysis of the hydrolytic activity of $A u$ AHLA using different substrates, we evaluated if this enzyme was also able to catalyze the synthesis reaction of those compounds in the appropriate reaction conditions. Kinetically controlled synthesis of penicillin V catalyzed by AuAHLA was carried out using 6-APA as acyl acceptor and MPOA as acyl donor. The effect of enzyme concentration and DMSO as co-solvent were studied. As it might be expected, synthetic activity $\left(\mathrm{V}_{\mathrm{s}}\right)$ and maximum yield $\left(\mathrm{Y}_{\max }\right)$ were increased as enzyme concentration was increased (Table 2) and reaction time for $Y_{\max }$ using $1 \mathrm{IU} / \mathrm{mL}$ AuAHLA was shorter than using 0.125 or $0.25 \mathrm{IU} / \mathrm{mL}$ AuAHLA. Figure 5A,B show the time-course reaction profiles using $1 \mathrm{IU} / \mathrm{mL} A u$ AHLA in the presence of $3 \%$ and $32 \%(v / v)$ DMSO, respectively. The percentage of DMSO did not affect the synthetic activity $\left(\mathrm{V}_{\mathrm{s}}\right)$ of $A u$ AHLA (Table 2$)$, whereas the hydrolytic activity $\left(\mathrm{V}_{\mathrm{h}}\right)$ was decreased when the concentration of DMSO in the reaction mixture was increased. These results agree with the previously observed reduction in penicillin $\mathrm{V}$ acylase activity in the presence of DMSO (Figure 4C). Because of this selective decrease in hydrolytic activity, the $\mathrm{S} / \mathrm{H}$ ratio was increased, reaching a slightly higher $Y_{\max }$ value in a longer reaction time than in the presence of $3 \%(v / v)$ DMSO. These differences could be due to the reduction in water activity $\left(\mathrm{a}_{\mathrm{w}}\right)$ of the system in the presence of DMSO as a co-solvent [36]. 
(A)

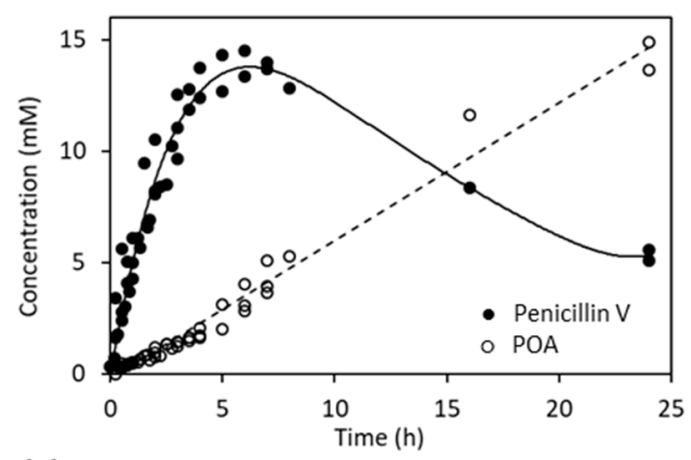

(C)

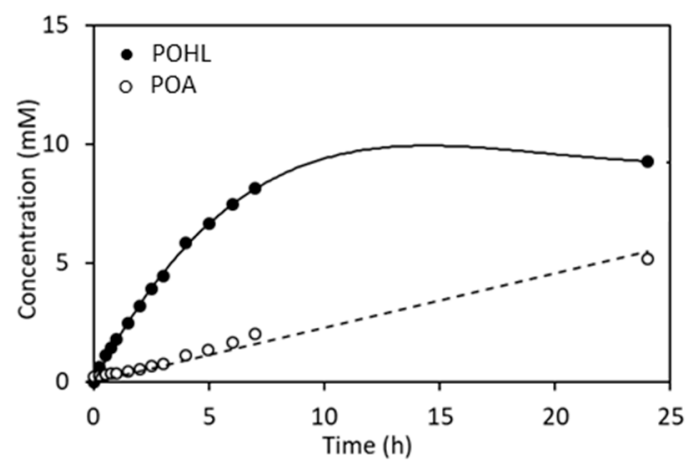

(B)

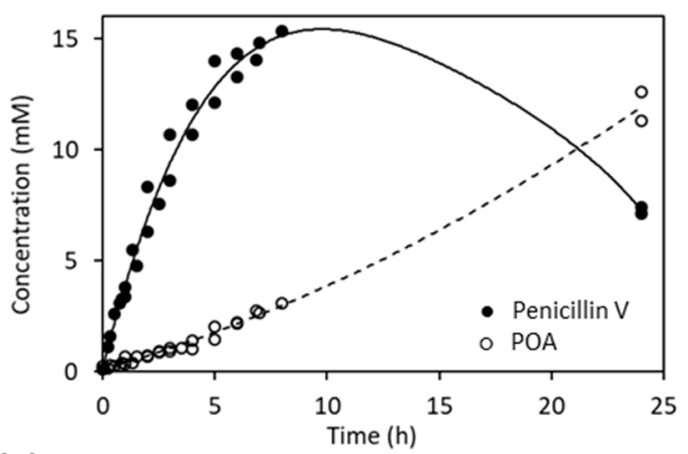

(D)

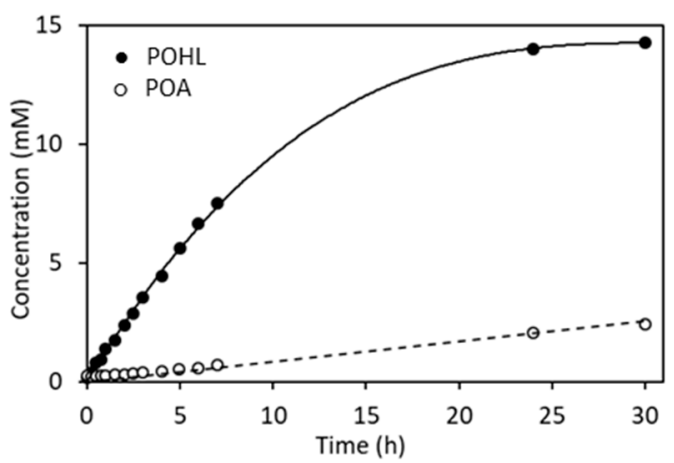

Figure 5. Synthetic activity of AuAHLA. Enzymatic synthesis of penicillin V catalyzed by AuAHLA in the presence of 3\% (A) and 32\% (v/v) DMSO (B) as co-solvent. Enzymatic synthesis of POHL catalyzed by AuAHLA in the presence of $23 \%$ (C) and 50\% (v/v) DMSO (D) as co-solvent. Reaction conditions: $1 \mathrm{IU} / \mathrm{mL}$ AuAHLA, $0.1 \mathrm{M}$ potassium phosphate $\mathrm{pH} 7.0$ buffer, $100 \mathrm{mM}$ acyl acceptor (6-APA or HSL), $20 \mathrm{mM}$ MPOA and $30{ }^{\circ} \mathrm{C}$.

Table 2. Parameters for the kinetically controlled synthesis of penicillin V and POHL catalyzed by AuAHLA.

\begin{tabular}{cccccccc}
\hline Product & $\boldsymbol{A} \boldsymbol{u}$ AHLA $(\mathbf{I U} / \mathbf{m L})$ & $\mathbf{D M S O} \mathbf{( \% )}$ & $\left.\mathbf{V}_{\mathbf{s}} \mathbf{( m M} / \mathbf{h}\right)$ & $\mathbf{V}_{\mathbf{h}} \mathbf{( m M / h )}$ & $\mathbf{S} / \mathbf{H}$ & $\mathbf{Y}_{\max }(\mathbf{\%})$ & Time for $\mathbf{Y}_{\max }(\mathbf{h})$ \\
\hline \multirow{3}{*}{ Penicillin V } & 0.125 & 3 & 0.85 & 0.40 & 2.13 & 30.8 & 24 \\
& 0.25 & 3 & 1.57 & 0.53 & 2.99 & 50.5 & 72.6 \\
\multirow{2}{*}{ POHL } & 1 & 3 & 3.81 & 0.55 & 6.94 & 76.8 & 6 \\
& 1 & 32 & 3.70 & 0.37 & 10.1 & 46.4 & 24 \\
\hline
\end{tabular}

Reaction conditions: $30^{\circ} \mathrm{C}, 0.1 \mathrm{M}$ potassium phosphate $\mathrm{pH} 7.0$ buffer, $100 \mathrm{mM}$ acyl acceptor (6-APA or HSL) and $20 \mathrm{mM}$ MPOA.

After observing that $A u$ AHLA was able to catalyze the enzymatic synthesis of penicillin V efficiently, its synthetic activity using L-HSL as acyl acceptor was studied. First, MPOA was used as an acyl donor. The synthesized AHLs analog, named phenoxyacetylHSL (POHL), was previously described and obtained by chemical procedures, as well as several derivatives with different substitutions [37]. These non-natural AHLs analogs, named aryl-L-homoserine lactones, can be used as antagonists for QS receptors to inhibit QS-regulated processes. Due to the low solubility of AHLs in water, POHL synthesis reactions catalyzed by $A u$ AHLA were carried out in the presence of $23 \%$ and $50 \%(v / v)$ DMSO (Figures 5C and 5D, respectively), and parameters for each reaction are shown in Table 2. While $\mathrm{V}_{\mathrm{s}}$ is similar in both conditions, $\mathrm{V}_{\mathrm{h}}$ is 3-fold lower when DMSO was increased from $23 \%$ to $50 \%(v / v)$, leading to a higher $\mathrm{S} / \mathrm{H}$ ratio and $\mathrm{Y}_{\max }$. Although $\mathrm{V}_{\mathrm{S}}$ is lower than for the synthesis of penicillin $\mathrm{V}, \mathrm{AuAHLA}$ can catalyze the enzymatic synthesis of POHL, reaching a similar $Y_{\max }$.

Moreover, enzymatic synthesis of natural AHLs was tested, using different fatty acid methyl esters as acyl donors and L-HSL as acyl acceptors. The molecular structure 
of synthesized AHLs was confirmed by LC-MS/MS analysis (Supplementary Material, Table S3). Due to the disadvantages of the chemical synthesis of these compounds, such as chemical wastes, long synthetic routes, and product purification processes, the enzymatic synthesis could be a very interesting alternative to obtain natural AHLs and reduce costs of AHL-based QS research.

\subsection{Bioassay Activity of Hydrolyzed and Synthetized AHLs by AuAHLA}

AHL acylase activity of $A u$ AHLA was also tested by the bioassay based on violacein production by Chromobacterium violaceum CV026 to confirm if this enzyme could be used in quorum quenching processes. The synthesis of violacein by $C$. violaceum $\mathrm{CV} 026$ is induced by AHLs with acyl chains from $C_{4}$ to $C_{8}$, while this process is inhibited by AHLs with acyl chains from $C_{10}$ to $C_{14}$. As it is shown in Figure 6A, $A u$ AHLA was able to inhibit violacein production using $\mathrm{C}_{6}$-HSL and $\mathrm{C}_{8}$-HSL because of their efficient enzymatic hydrolysis (forward bioassay). Regarding 3-oxo- $\mathrm{C}_{6}-\mathrm{HSL}$ and 3-oxo- $\mathrm{C}_{8}-\mathrm{HSL}$, enzymatic hydrolysis was not observed. In contrast to this, violacein production by $C$. violaceum $\mathrm{CV} 026$ was induced in all reverse bioassay plates, indicating that $A u$ AHLA was able to efficiently hydrolyze AHLs with long acyl chains both aliphatic- and 3-oxo substituted. These results, together with the kinetic parameters determined for the hydrolysis of AHLs (Table 1), demonstrate that $A u$ AHLA has AHL acylase activity and suggest its potential use as a QQ agent to disrupt QS processes.

Furthermore, the bioactivity of non-natural POHL and natural AHLs synthesized by $A u$ AHLA was also qualitatively analyzed using C. violaceum CV026 (Figure 6B). No synthetic activity for $\mathrm{C}_{4}$-HSL was observed, whereas enzymatic synthesized POHL, $\mathrm{C}_{6}-\mathrm{HSL}$, $\mathrm{C}_{8}$-HSL, and 3-oxo- $\mathrm{C}_{6}$-HSL induced the production of violacein. Likewise, enzymatically synthesized $\mathrm{C}_{10}-\mathrm{HSL}, \mathrm{C}_{12}-\mathrm{HSL}$, 3-oxo- $\mathrm{C}_{10}-\mathrm{HSL}$, and 3-oxo- $\mathrm{C}_{12}-\mathrm{HSL}$ inhibited the production of violacein by $C$. violaceum $\mathrm{CV} 026$ in the presence of $\mathrm{C}_{6}$-HSL as autoinducer.

(A)

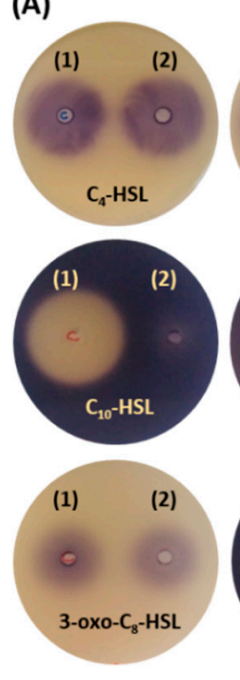

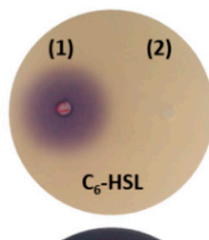
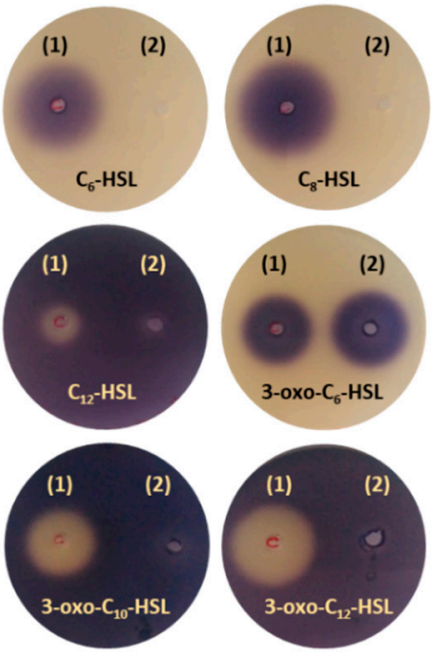

(B)

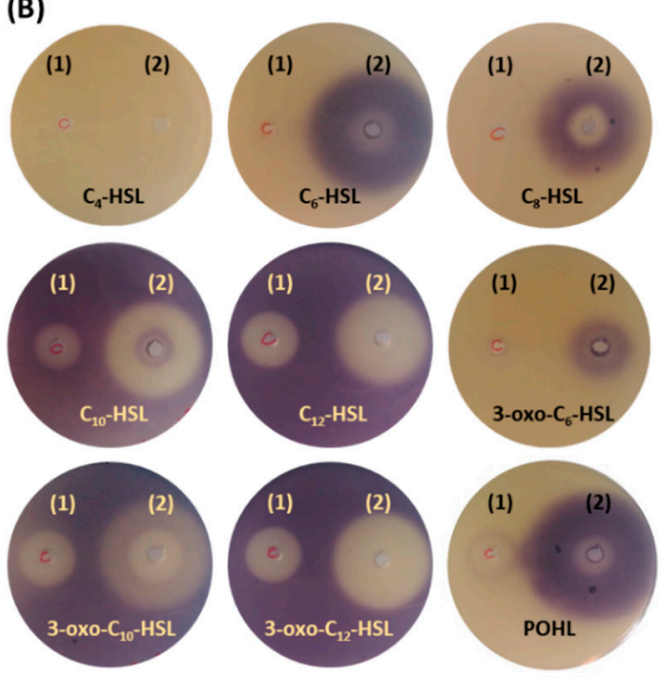

Figure 6. Chromobacterium violaceum CV026 bioassays testing the hydrolysis of AHLs (A) and the enzymatic synthesized AHLs and POHL by AuAHLA (B). In each agar plate, spot (1) contains the reaction mixture without AuAHLA, and spot (2) contains the enzymatic reaction mixture.

\section{Discussion}

The ahla gene from Actinoplanes utahensis NRRL 12052 has been successfully cloned and extracellularly expressed in the recombinant strain Rhodococcus pENV19ahla, showing that it encodes for the acylase $A u$ AHLA, which has been correctly post-translational processed. This fact demonstrates that Rhodococcus is an adequate expression host for actinomycetes' genes $[29,38,39]$. Moreover, the resulting mature and active enzyme has been purified in a single chromatographic step. 
$\mathrm{N}$-terminal amino acid sequence analysis has confirmed that $A u$ AHLA belongs to the Ntn-hydrolase superfamily with a heterodimeric structure and a serine as nucleophilic catalytic residue. Moreover, sequence alignment analysis has shown that putative catalytic amino acids are highly conserved with respect to other acylases (Supplementary Material, Figure S1 and Table S1).

Based on phylogenetic analysis, AuAHLA belongs to the AHL acylase group A within the Ntn-hydrolase superfamily (Supplementary Material, Figure S3), such as other related acylases: AuAAC from A. utahensis [24,28], SmPVA from Streptomyces mobaraensis [30], SlPVA from S. lavendulae [29,40], SsCLA from Streptomyces sp. FERM-BP5809 [32], and AhlM from Streptomyces sp. M664 [31]. Other members of this group are: QqaR from Deinococcus radiodurans [41], Aac from Ralstonia solanacearum [42], AiiD from Ralstonia sp. XJ12B [43], AhaP from Psychrobacter sp. M9-54-1 [44], MacQ from Acidovorax sp. MRS7 [45], HacA from Pseudomonas syringae B728a [46], PvdQ from P. aeruginosa PAO1 [47], and Aac from Shewanella sp. [48]. This AHL acylase group A is distant from the AHL acylase group B, which is closer to the PGA group. A separate cluster is formed by the cholylglycine hydrolase (CGH) group, together with the amidase group. CGH group includes PVAs and bile salt hydrolases (BSHs), having significant sequence, structural and catalytic mechanism similarities [49]. Though, the acylases Slac1 and Slac2 located in this last group have shown AHL acylase activity, whereas they are inactive on CGH substrates, $\beta$-lactam antibiotics, or bile salts [50]. Apart from AuAHLA, other Ntn-hydrolases from different groups have shown both penicillin and AHL acylase activity (Supplementary Material, Figure S3, enzymes with asterisk) such as AhlM [31], MacQ [45], PfmA from Pseudoalteromonas flavipulchra JG1 [51], KcPGA from Kluyvera citrophila [52], AtPVA from Agrobacterium tumefaciens, and PaPVA from Pectobacterium atrosepticum [19]. Among these bifunctional enzymes, SlPVA and $A u \mathrm{AAC}$ have also shown aculeacin A acylase activity [53].

Regarding substrate specificity, $A u$ AHLA can hydrolyze different natural penicillins and several $\mathrm{N}$-acyl-L-homoserine lactones, both aliphatic and 3-oxo substituted. The best catalytic efficiency has been determined for penicillin $\mathrm{V}$, followed by $\mathrm{C}_{12}$-HSL. Surprisingly, catalytic efficiency using penicillin $\mathrm{V}$ as a substrate is 2.4-fold higher than $\mathrm{C}_{12}-\mathrm{HSL}$ and 7.3-fold higher than $\mathrm{C}_{10}$-HSL (Table 2). Kinetic parameters are drastically decreased using AHLs with 3-oxo substitution, and no catalytic activity was detected using $\mathrm{C}_{4}-\mathrm{HSL}$, 3oxo- $\mathrm{C}_{6}-\mathrm{HSL}$, aculeacin A, and caspofungin as substrate. AuAHLA showed a catalytic efficiency for penicillin G 100-fold lower than for penicillin V, despite this enzyme is a heterodimer with an N-terminal catalytic Ser similar to PGAs and in contrast to PVAs, which are usually homotetrameric with a Cys at the N-terminal [49]. This unusual 3D structure has also been previously described for SmPVA [30] and SlPVA [29]. Catalytic efficiencies of $A u$ AHLA using natural penicillins as substrate (Table 2) are significantly higher than those previously reported for $A u A A C\left(34.79\right.$ and $4.55 \mathrm{mM}^{-1} \mathrm{~s}^{-1}$ for penicillin $\mathrm{K}$ and V, respectively) [28] and SlPVA $\left(38.88,21.85\right.$, and $0.075 \mathrm{mM}^{-1} \mathrm{~s}^{-1}$ for penicillin V, dihydroF and G, respectively) [54]. Moreover, $A u$ AHLA shows a catalytic efficiency for penicillin $\mathrm{G}$ similar to $\operatorname{SmPVA}\left(2.1 \mathrm{mM}^{-1} \mathrm{~s}^{-1}\right)$, while it is significantly higher for penicillin $\mathrm{V}\left(51.9 \mathrm{mM}^{-1} \mathrm{~s}^{-1}\right)$ [30].

Comparable substrate specificity of $A u$ AHLA has also been described for other acylases such as AhlM from Streptomyces sp. strain M664, which can degrade penicillin G and AHLs with acyl chains of eight carbons or more [31]. However, scarce kinetic data of AHL acylase activity have been reported, highlighting the studies with PvdQ and HacB from $P$. aeruginosa [55,56], KcPGA [52], and penicillin V acylases from Pectobacterium atrosepticum (PaPVA) and Agrobacterium tumefaciens (AtPVA) [19]. It should be considered that kinetic parameters using a broad range of AHLs have been determined in this study, as well as previously described for SlPVA and AuAAC [53], while a few AHLs have been used as substrate in other acylases kinetic studies.

Results observed in bioassay plate tests with Chromobacterium violaceum CV026 suggest the potential application of $A u$ AHLA as a QQ agent. Similar results have been previously reported using SlPVA and AuAAC [53], but the inhibitory effect on violacein production is 
larger and more evident using AuAHLA. The wide AHLs specificity of AuAHLA suggests that it could be an attractive enzyme for protein engineering to improve its properties as a quorum quenching agent.

Noteworthy, AuAHLA has efficiently synthesized penicillin V, confirming that this enzyme can carry out both acylation and deacylation of this substrate depending on the reaction conditions. Penicillin V synthetic parameters of $A u$ AHLA can be compared with the observed for SIPVA in similar reaction conditions [36]. In presence of $2.7 \%(v / v)$ DMSO, $0.3 \mathrm{IU} / \mathrm{mL}$ SlPVA reaches a higher $\mathrm{Y}_{\max }(94.5 \%)$ and higher $\mathrm{S} / \mathrm{H}$ ratio (16.4). However, in presence of $40 \%(v / v)$ DMSO, $1 \mathrm{IU} / \mathrm{mL}$ SlPVA reaches a $\mathrm{Y}_{\max }$ of $81 \%$, similar to $1 \mathrm{IU} / \mathrm{mL}$ $A u$ AHLA in $32 \%(v / v)$ DMSO. Although the S/H ratio is lower for AuAHLA than SlPVA in both conditions, the reaction time for $Y_{\max }$ of $A u$ AHLA is shorter than SlPVA. In addition, penicillin $\mathrm{V}$ synthesis by $A u$ AHLA has reached a $\mathrm{Y}_{\max }$ and $\mathrm{S} / \mathrm{H}$ ratio higher than SmPVA in similar conditions (66\% and 3.2, respectively) [57].

Moreover, $A u$ AHLA has catalyzed the enzymatic synthesis of natural AHLs such as $\mathrm{C}_{6}$-HSL, $\mathrm{C}_{8}$-HSL, $\mathrm{C}_{10}$-HSL, $\mathrm{C}_{12}$-HSL, 3-oxo-C 6 -HSL, 3-oxo- $\mathrm{C}_{10}$-HSL, and 3-oxo- $\mathrm{C}_{12}$-HSL, and the non-natural analog $\mathrm{POHL}$, under the appropriate reaction conditions. Although enzymatic synthesis of POHL was slower than synthesis of penicillin $V$ and needed a higher concentration of DMSO due to the low solubility of AHLs in water, both synthetic reactions reached a quite similar $Y_{\max }$. Currently, necessary AHLs for QS research are obtained by different strategies of chemical synthesis [14,58-60]. To date, only one example of enzymatic synthesis of aliphatic and hydroxylated AHLs has been described, using immobilized lipase from Candida antarctica (CAL) [61]. However, this study using the acylase AuAHLA is the first enzymatic synthesis report of 3-oxo-AHLs and non-natural aryl-HSLs. Enzymatic synthesis of AHLs and non-natural analogs could present several advantages over chemical synthesis, being a faster process with less solvent waste. Furthermore, biocatalysts are biocompatible, biodegradable, and non-toxic, enzymatic reactions are highly regio-, stereo-, and chemoselective, and they could be carried out at moderated temperature and pressure conditions $[62,63]$.

As mentioned above, non-natural AHLs analogs can be used as QQ agents by blocking the QS receptor. In contrast to other QQ strategies, autoinducers analogs show some advantages, such as they are often highly diffusible through biological membranes, leading to a rapid QS inhibition that can be reversible or irreversible depending on the molecule used. Several substituted derivatives of POHL have been previously evaluated as QS receptor modulators, confirming their potential as QS antagonists. In particular, 4- $\mathrm{NO}_{2}-$ POHL was a potent antagonist for the QS receptor TraR from Agrobacterium tumefaciens and 4-Br- and 4-I-POHL were antagonists for both receptors TraR from $A$. tumefaciens and LasR from Pseudomonas aeruginosa [37]. For this reason, it would be interesting to enzymatically synthesize POHL that could be used as a synthetic scaffold for obtaining these non-natural aryl-HSLs.

\section{Materials and Methods}

\subsection{Chemical Reagents}

Cell culture media were purchased from Becton-Dickinson (Franklin Lakes, NJ, USA); chemical reagents such as methanol, acetic acid and potassium phosphate from Fisher Scientific (Waltham, MA, USA); $N$-acyl-L-homoserine lactones (except $N$-(3-oxohexanoyl)L-homoserine lactone, which was from Santa Cruz Biotechnology, Dallas, TX, USA), Lhomoserine lactone hydrochloride (HSL), penicillin V, phenoxyacetic acid (POA), methyl phenoxyacetate (MPOA), methyl hexanoate, methyl decanoate, $p$-dimethylaminobenzaldehyde (PDAB), o-phthalaldehyde (OPA), kanamycin, and DMSO from Sigma-Aldrich (Burlington, MA, USA); methyl octanoate and methyl dodecanoate from Fluka (Burlington, MA, USA); methyl butyrate from Acros Organics (Waltham, MA, USA); methyl butyrylacetate from Alfa Aesar (Tewksbury, MA, USA); and methyl 3-oxodecanoate and methyl 3-oxododecanoate from Toronto Research Chemicals (Toronto, ON, Canada). 6-aminopenicillanic acid (6-APA) and natural aliphatic penicillins (penicillin $\mathrm{K}$, penicillin $\mathrm{F}$ and penicillin dihydro-F) were 
provided by Antibióticos S.A. (León, Spain). All reagents used showed a purity level of at least $\geq 95 \%$. Oligonucleotides were synthesized by Sigma-Aldrich (Burlington, MA, USA).

\subsection{Microorganisms, Culture Conditions, Plasmids, and DNA Manipulation}

Bacterial strains, plasmids, and oligonucleotides used are listed in Table 3. Actinoplanes utahensis NRRL 12052 was used as the DNA source [23], Escherichia coli DH5 $\alpha$ was used as the host for subcloning experiments [64], and Rhodococcus sp. T104 KACC 21099 was used as the host for gene expression [38]. A. utahensis was cultured in S-YEME (yeast extract, malt extract, $0.5 \%$ glycine) liquid medium at $30^{\circ} \mathrm{C}$ [65], Rhodococcus was grown in 2xYTG (yeast extract, bacto tryptone, $\mathrm{NaCl}$, glucose) medium at $30^{\circ} \mathrm{C}$ [38], and E. coli was cultured in Luria-Bertani (LB) medium at $37^{\circ} \mathrm{C}$ [66]. Chromobacterium violaceum CV026 CECT 5999 was grown in LB agar plates at $30^{\circ} \mathrm{C}$ for bioassays [67]. Bifunctional plasmids pEM4 [68] and pNV19 [69] were used to construct the E. coli-Rhodococcus shuttle vector pENV19 [39] for gene expression in Rhodococcus sp. T104. For that, the fragment of $227 \mathrm{bp}$ containing the strong ermE* promoter and the MCS of the pEM4 vector was cloned between HindIII and EcoRI restriction site in pNV19 (Supplementary Material, Figure S4).

Plasmid purification was performed using the PureLink Quick Plasmid Miniprep Kit from Invitrogen (Waltham, MA, USA). Plasmidic DNA was sequenced according to Sanger [70] by BigDye Terminator v3.1 with an automatic DNA sequencer ABI Prism 3730 (Applied Biosystems Inc, Waltham, MA, USA) in Secugen S. L.

Table 3. Bacterial strains, plasmids, and primers ${ }^{\#}$ used.

\begin{tabular}{|c|c|c|}
\hline Strain, Plasmid, or Primer & Relevant Description or Sequence & Reference \\
\hline Actinoplanes utahensis NRRL 12052 & Native $N$-acyl-homoserine lactone acylase producer & {$[23,24,71]$} \\
\hline Escherichia coli DH5 $\alpha$ & $\begin{array}{c}\text { Host for recombinant plasmid } \\
\mathrm{F}^{-} \lambda-\varphi 80 \mathrm{~d} l a c Z \Delta \mathrm{M} 15 \Delta\left(\text { lacZYA-argF) U169 recA1 endA1 hsdR17( } \mathrm{r}_{\mathrm{K}}^{-}\right. \\
\mathrm{m}_{\mathrm{K}^{+}}{ }^{-} \text {supE44 thi-1 gyrA96 relA1 }\end{array}$ & [64] \\
\hline Rhodococcus sp. T104 KACC 21099 & Host for gene expression $\left(K n^{\mathrm{s}}\right)$ & [38] \\
\hline Rhodococcus pENV19ahla & Recombinant strain harboring the plasmid pENV19ahla & This study \\
\hline $\begin{array}{l}\text { Chromobacterium violaceum CV026 CECT } \\
5999\end{array}$ & $\begin{array}{l}\text { cvil::mini-Tn5-mutant of Chromobacterium violaceum ATCC } 31532 \\
\qquad\left(\mathrm{Kn}^{\mathrm{R}}\right)\end{array}$ & [67] \\
\hline pENV19 & $\begin{array}{l}\text { Shuttle vector for E. coli-Rhodococcus with the constitutive permE } \\
\text { promoter }\left(5.1 \mathrm{~Kb}, \mathrm{~K} n^{\mathrm{R}} \text { pAL5000ori permE }{ }^{*} \text { ColE1ori) }\right.\end{array}$ & {$[29,38,39]$} \\
\hline pENV19ahla & pENV19-containing ahla gene from $A$. utahensis NRRL 12052 & This study \\
\hline AHLA1 & 5'-GCTCTAGAGGAGGTGCCGCCGTGGCCCGTCCGTTCA-3' & This study \\
\hline AHLA2 & 5'-CGGAATTCCTCACCGCGGCGCTCGCTCGGTCAGTCTGAT-3' & This study \\
\hline
\end{tabular}

\# The restriction sites $\mathrm{XbaI}$ and EcoRI are shown in bold, ribosomal binding site sequence is shown in italics, and the start and the stop codons are shown underlined.

4.3. Overexpression of ahla Gene and Purification of Recombinant AuAHLA from Rhodococcus sp. T104

The hypothetical ahla gene (GenBank accession no. NZ_JRTT01000008.1), including its signal peptide coding sequence and the putative RBS sequence (GGAGG), was amplified by PCR using PfuDNA polymerase (Thermo, Waltham, MA, USA) and genomic DNA from A. utahensis NRRL 12052 [23] as a template. PCR was performed in Mastercycler Personal equipment (Eppendorf, Hamburg, Germany), and amplification conditions were set according to the high $\mathrm{G}+\mathrm{C}$ content of the actinomycetes genome [29,39]. XbaI and EcoRI restriction sites were included in the primers (Table 1) in order to subclone the PCR product in pENV19 vector. PCR products were purified by the commercial kit illustra GFX PCR DNA and Gel Band Purification (GE Healthcare, Chicago, IL, USA). Recombinant plasmid pENV19ahla was used to transform electrocompetent Rhodococcus sp. T104 cells [38]. 
To purify the recombinant $A u$ AHLA (NCBI accession no. WP_052163432.1), the strain Rhodococcus pENV19ahla was cultivated in 2× YTG liquid medium with $100 \mu \mathrm{g} / \mathrm{mL}$ kanamycin at $30{ }^{\circ} \mathrm{C}$ for $72 \mathrm{~h}$ and $250 \mathrm{rpm}$ orbital shaking. Cell-free supernatant was harvested by centrifugation at $3500 \times g$ and adjusted at $\mathrm{pH}$ 6.0. The enzyme was purified from the culture broth by cation-exchange chromatography on an SP-Sepharose Fast Flow column (Amersham Biosciences, Buckinghamshire, UK), equilibrated with $10 \mathrm{mM}$ potassium phosphate $\mathrm{pH} 6.0$ buffer. The enzyme was eluted with a linear gradient of $\mathrm{NaCl}$ $(0-1 \mathrm{M})$ in the same buffer at a flow rate of $1 \mathrm{~mL} / \mathrm{min}$ using an NGC Chromatography System (Bio-Rad, Hercules, CA, USA). The fractions showing acylase activity were pooled and concentrated by ultrafiltration, using an Amicon Ultra-15 filter (Millipore, Burlington, MA, USA). The purity of the protein was analyzed by $12.5 \%(w / v)$ SDS-PAGE, and protein concentration was determined according to Bradford [72].

\subsection{Protein Sequence and Structure Analysis}

To determine the $\mathrm{N}$-terminal amino acid sequence, the protein bands after SDS-PAGE were transferred to a PVDF membrane Immobilon-P (Millipore, Burlington, MA, USA) [73] and sequenced by automatic Edman degradation in a Procise 494 Protein Sequencing System (Applied Biosystems Inc., Waltham, MA, USA) in the Protein Chemistry Facility (CIB-CSIC). The molecular weight and peptide fingerprinting analysis were performed on an Autoflex III MALDI-TOF/TOF instrument (Bruker Daltonics, Billerica, MA, USA) with a smart beam laser in the Proteomics and Genomics Facility (CIB-CSIC).

Circular dichroism (CD) spectra were recorded using a Jasco (Tokio, Japan) J-715 spectropolarimeter with a thermostated $0.1-\mathrm{cm}$-path-length quartz cell in the far-UV region. The $C D$ readings were expressed as the mean residue molar ellipticity $\left(\operatorname{deg} \mathrm{cm}^{2} \mathrm{dmol}^{-1}\right)$, and secondary structure information was obtained from CD spectra by using the CDNN V2.1 [74].

Analytical ultracentrifugation experiments were carried out with an Optima XLA ultracentrifuge (Beckman-Coulter, Brea, CA, USA) in the Molecular Interactions Facility (CIB-CSIC). Sedimentation coefficients $(S)$ were obtained from the sedimentation velocity results, analyzed with SEDFIT version 16.1c software.

Transmission electron microscopy (TEM) analysis was performed in the Electron Microscopy Facility (CIB-CSIC). Micrographs were taken with a JEOL (Peabody, MA, USA) transmission electron microscope JEM-1230 operated at $100 \mathrm{kV}$ and equipped with a digital camera CMOS TVIPS TemCam-F416 at nominal magnification of X5000. Protein samples were negatively stained with $1 \%(w / v)$ uranyl acetate on Formvar grids. Single images corresponding to $A u$ AHLA particles were extracted using the EMAN program (developed by National Center for Macromolecular Imaging, Houston, TX, USA) [75].

\subsection{Acylase Activity Assay}

Acylase activity was routinely assayed, incubating $70 \mathrm{mM}$ penicillin $\mathrm{V}$ in $0.3 \mathrm{M}$ potassium phosphate $\mathrm{pH} 8.0$ buffer at $45^{\circ} \mathrm{C}$ for $20 \mathrm{~min}$ and $450 \mathrm{rpm}$. The enzymatic reaction was stopped by adding $20 \%(v / v)$ acetic acid, and 6-APA released was detected by adding $0.5 \%(w / v)$ PDAB reagent dissolved in methanol and measuring the absorbance at $405 \mathrm{~nm}$ [76]. All measurements were carried out in triplicate. One international activity unit (IU) was defined as the amount of enzyme-producing $1 \mu \mathrm{mol} / \mathrm{min}$ of 6 -APA under the described assay conditions.

\subsection{Biochemical Characterization and Kinetic Parameters}

The optimum $\mathrm{pH}$ of purified AuAHLA was determined by assaying the activity at different $\mathrm{pH}$ values (4-11) in $20 \mathrm{mM}$ citrate-phosphate-borate buffer with $220 \mathrm{mM}$ constant ionic strength at $45^{\circ} \mathrm{C}$. The optimum temperature was also determined by assaying the activity at several temperatures $\left(20-60^{\circ} \mathrm{C}\right)$ in $0.3 \mathrm{M}$ potassium phosphate $\mathrm{pH} 8.0$ buffer. To determine $\mathrm{pH}$ stability, $0.1 \mu \mathrm{g}$ of $\mathrm{AuAHLA}$ were incubated in $20 \mathrm{mM}$ citrate-phosphateborate buffer at $\mathrm{pH}$ values from 4 to 11 , for $20 \mathrm{~min}$ at $4{ }^{\circ} \mathrm{C}$. Residual acylase activity was 
assayed under optimal conditions, as described above. Thermal stability was also studied by incubating $0.1 \mu \mathrm{g}$ of $A u$ AHLA at various temperatures $\left(20-60^{\circ} \mathrm{C}\right)$ for $20 \mathrm{~min}$ in $0.3 \mathrm{M}$ potassium phosphate $\mathrm{pH} 8.0$ buffer. After $10 \mathrm{~min}$ in an ice bath, residual acylase activity was measured at $45{ }^{\circ} \mathrm{C}$ as described above. All assays were carried out in triplicate.

Kinetic parameters of $A u$ AHLA were determined using the following penicillins and L-enantiopure AHLs: penicillin $\mathrm{V}$, penicillin $\mathrm{K}$, penicillin dihydroF, penicillin $\mathrm{G}, \mathrm{N}$-butanoylL-homoserine lactone $\left(\mathrm{C}_{4}-\mathrm{HSL}\right), \mathrm{N}$-hexanoyl-L-homoserine lactone $\left(\mathrm{C}_{6}\right.$-HSL), $\mathrm{N}$-octanoyl-Lhomoserine lactone ( $\mathrm{C}_{8}$-HSL), $\mathrm{N}$-decanoyl-L-homoserine lactone $\left(\mathrm{C}_{10}-\mathrm{HSL}\right), \mathrm{N}$-dodecanoylL-homoserine lactone ( $\mathrm{C}_{12}$-HSL), $\mathrm{N}$-(3-oxohexanoyl)-L-homoserine lactone (3-oxo- $\mathrm{C}_{6}$-HSL), $\mathrm{N}$-(3-oxooctanoyl)-L-homoserine lactone (3-oxo- $\mathrm{C}_{8}$-HSL), $\mathrm{N}$-(3-oxodecanoyl)-L-homoserine lactone (3-oxo- $\left.\mathrm{C}_{10}-\mathrm{HSL}\right)$, and $\mathrm{N}$-(3-oxododecanoyl)-L-homoserine lactone (3-oxo- $\mathrm{C}_{12}-\mathrm{HSL}$ ). Enzymatic reactions containing $0.18 \mu \mathrm{g}$ of $A u \mathrm{AHLA}, 20 \mu \mathrm{L}$ of increasing concentrations of penicillins (dissolved in water) or AHLs (dissolved in DMSO) and $0.2 \mathrm{M}$ potassium phosphate pH 8.0 buffer (final volume of $100 \mu \mathrm{L}$ ), were incubated at $45^{\circ} \mathrm{C}$ for $10 \mathrm{~min}$ and $450 \mathrm{rpm}$. Primary amines released during the enzymatic reactions were determined by the fluorometric assay according to Velasco-Bucheli et al. [53]. The enzymatic reaction was mixed with OPA reagent, and fluorescence intensity was determined employing a Thermo Varioskan LUX (Thermo, Waltham, MA, USA) with $355 \mathrm{~nm}$ and $460 \mathrm{~nm}$ as excitation and emission wavelengths, respectively. All enzymatic reactions were carried out in triplicate. Kinetics curves were fitted to equation: $v=\left(\mathrm{V}_{\max } \times \mathrm{S}\right) /\left(\mathrm{K}_{\mathrm{m}}+\mathrm{S}\right)$, and kinetic constants were determined by nonlinear regression using Hyper32 program (available online: http:/ / homepage.ntlworld.com/john.easterby/hyper32.html, accessed on January 2020).

\subsection{Enzymatic Synthesis of Penicillin $V$ and AHLs}

Kinetically controlled synthesis of penicillin V by AuAHLA was carried out according to Hormigo et al. [36] with slight modifications. The reaction mixture containing $1 \mathrm{IU} / \mathrm{mL}$ AuAHLA, $100 \mathrm{mM}$ 6-APA, $20 \mathrm{mM}$ MPOA and 3\% or 32\% (v/v) DMSO, was incubated in $100 \mathrm{mM}$ potassium phosphate $\mathrm{pH} 7.0$ buffer at $30^{\circ} \mathrm{C}$ and $800 \mathrm{rpm}$. At different incubation times, $20 \mu \mathrm{L}$ of the enzymatic reaction were mixed with $20 \mu \mathrm{L}$ of cold methanol and analyzed by HPLC using an Agilent 1100 equipment (Santa Clara, CA, USA) and a Phenomenex (Torrance, CA, USA) Luna column C18(2), $250 \times 4.6 \mathrm{~mm}(5 \mu \mathrm{M}$ particle size); with a $65 \%(v / v)$ methanol solution containing $0.05 \%(v / v)$ phosphoric acid as mobile phase. The flow rate was fixed at $0.8 \mathrm{~mL} / \mathrm{min}$, and the UV detector was set at $260 \mathrm{~nm}$. Retention times of substrates and products were 4.0 (6-APA), 6.6 (POA), 9.6 (MPOA), and $11.3 \mathrm{~min}$ (penicillin V). Concentrations of penicillin V, POA, and MPOA were estimated with calibration curves using standard solutions. All determinations were carried out in triplicate. Synthetic activity $\left(\mathrm{V}_{\mathrm{S}}\right)$ was established as the initial rate of synthesis (penicillin $\mathrm{V}$ production per unit time, expressed as $\mathrm{mM} / \mathrm{h})$, whereas hydrolytic activity $\left(\mathrm{V}_{\mathrm{h}}\right)$ was established as the initial rate of hydrolysis of MPOA (POA production per unit time, expressed as $\mathrm{mM} / \mathrm{h}$ ). The ratio of synthetic activity to hydrolytic activity ( $\mathrm{S} / \mathrm{H}$ ratio) was calculated as $\mathrm{V}_{\mathrm{S}} / \mathrm{V}_{\mathrm{h}}$.

Enzymatic synthesis of AHLs were carried out with $2 \mathrm{IU} / \mathrm{mL}$ AuAHLA, $100 \mathrm{mM}$ L-HSL, $20 \mathrm{mM}$ acyl donor (methyl butyrate, hexanoate, octanoate, decanoate, dodecanoate, butyrylacetate, 3-oxodecanoate, or 3-oxododecanoate), and $23 \%$ or $50 \%(v / v)$ DMSO in $100 \mathrm{mM}$ potassium phosphate $\mathrm{pH} 7.0$ buffer. These mixtures were incubated at $30^{\circ} \mathrm{C}$ and $800 \mathrm{rpm}$ for $24 \mathrm{~h}$, and then the samples were evaporated at $45^{\circ} \mathrm{C}$ to dryness using a speed vacuum concentrator Thermo Scientific SPD121P (Waltham, MA, USA), stored at $-20^{\circ} \mathrm{C}$, and dissolved in methanol prior to analysis. Enzymatic synthesized AHLs were analyzed by LC-MS/MS using a Shimadzu LCMS8030 (Kyoto, Japan) equipment and a Phenomenex (Torrance, CA, USA) Gemini Column C18 $110 \AA$ (150 × 2 mm $5 \mu \mathrm{m}$ particle size) with a Phenomenex C18 pre-column $(4 \times 2 \mathrm{~mm})$ in the Mass Spectrometry Facility (Faculty of Chemistry, UCM). Mobile phase A was water and mobile phase B was methanol, and the gradient profile was as follows: $0 \%$ phase $B$ for $1 \mathrm{~min}$, from $0 \%$ to $100 \%$ phase $B$ for $5 \mathrm{~min}, 100 \%$ phase B for $1.5 \mathrm{~min}$, from $100 \%$ to $0 \%$ phase $B$ for $1 \mathrm{~min}$ and $0 \%$ phase $B$ for 
$1.5 \mathrm{~min}$ at a flow rate of $0.4 \mathrm{~mL} / \mathrm{min}$. Analysis of AHLs was performed by multiple reaction monitoring (MRM) mode to monitor de parent ion-product ion $(\mathrm{m} / \mathrm{z})$ of the analyte, and mass transitions of each molecule are listed in Supplementary Material, Table S3.

\subsection{Bioassay Activity of Hydrolyzed and Synthetized AHLs Using Chromobacterium violaceum CV026}

Bioactive AHLs hydrolyzed by AuAHLA were tested using C. violaceum CV026 [53,67]. Hydrolysis reactions of different AHLs were carried out in $50 \mu \mathrm{L}$ containing $1 \mathrm{mM}$ of the corresponding AHL, $0.5 \mathrm{IU} / \mathrm{mL}$ AuAHLA, $100 \mathrm{mM}$ potassium phosphate $\mathrm{pH} 8.0$ buffer and $10 \%(v / v)$ DMSO and were incubated at $45^{\circ} \mathrm{C}$ for $2 \mathrm{~h}$ and $450 \mathrm{rpm}$. Then, these mixtures were applied in wells punched in LB agar medium with preinduced C. violaceum CV026 and incubated at $30^{\circ} \mathrm{C}$ for $24 \mathrm{~h}$ (forward bioassay). For enzymatic reactions using AHLs with acyl chains longer than $\mathrm{C}_{8}-\mathrm{HSL}$, the reverse bioassay was performed, adding $5 \mu \mathrm{M}$ $\mathrm{C}_{6}$-HSL to the agar plates together with C. violaceum CV026 [53]. Similarly, the synthesis of bioactive AHLs was tested using an aliquot of $50 \mu \mathrm{L}$ of each reaction mixture after $24 \mathrm{~h}$ at $30^{\circ} \mathrm{C}$ following the protocol described above.

\section{Conclusions}

AuAHLA can hydrolyze a broad range of substrates, including different natural penicillins and several $\mathrm{N}$-acyl-L-homoserine lactones, both aliphatic and 3-oxo substituted. Moreover, this enzyme shows quorum quenching activity since it inhibits the production of violacein by $C$. violaceum CV026.

$A u$ AHLA is the first reported AHL acylase capable of synthesizing different bioactive $\mathrm{N}$-acyl-L-homoserine lactones, both aliphatic and 3-oxo substituted, using L-HSL and methyl fatty acids as substrates. Enzymatic synthesis of AHLs arises as an alternative method that might be faster, cheaper, and eco-friendlier than the organic synthesis of these compounds. Furthermore, this enzymatic method could allow obtaining non-natural analogs of AHLs to block QS receptors and inhibit the signal of autoinducers.

Supplementary Materials: The following are available online at https: / www.mdpi.com/article / 10.3390/antibiotics10080922/s1, Figure S1: Multiple amino acid sequence alignment of AuAHLA and other acylases from the Ntn-hydrolase superfamily by ClustalW. Figure S2: Purified AuAHLA analysis. Figure S3: Phylogenetic analysis of $A u$ AHLA and other acylases from the Ntn-hydrolase superfamily. Figure S4: Shuttle vector pENV19 construction. Table S1: Amino acids involved in the catalysis predicted by COBALT sequence alignment using AuAHLA, SlPVA, AuAAC, and other 174 acylases and their characteristics. Table S2: Purification table of AuAHLA by ionic exchange chromatography. Table S3: MRM parameters of AHLs analysis.

Author Contributions: Conceptualized by L.S.-A., A.S., M.A. and I.d.I.M.; Experiments designed by L.S.-A., R.V.-B., B.G.-Á., M.A. and I.d.I.M.; Experiments conducted by L.S.-A., R.V.-B. and B.G.-Á.; Data analyzed by L.S.-A., A.S., M.A. and I.d.l.M.; Writing—original draft preparation by L.S.-A. and I.d.I.M.; Manuscript revision and editing by L.S.-A., R.V.-B., A.S., B.G.-Á., M.A. and I.d.l.M.; Funding acquisition: I.d.l.M. Supervision: I.d.l.M. All authors have read and agreed to the published version of the manuscript.

Funding: This work was supported by the Ministry of Economy, Industry and Competitiveness of Spain, CTQ2014-60250-R project.

Institutional Review Board Statement: Not applicable.

Informed Consent Statement: Not applicable.

Data Availability Statement: The data presented in this study are fully available in the main text and Supplementary Material of this article.

Conflicts of Interest: The authors declare no conflict of interest. 


\section{References}

1. Papenfort, K.; Bassler, B.L. Quorum sensing signal-response systems in Gram-negative bacteria. Nat. Rev. Microbiol. 2016, 14, 576-588. [CrossRef] [PubMed]

2. Fuqua, W.C.; Winans, S.C.; Greenberg, E.P. Quorum sensing in bacteria: The LuxR-LuxI family of cell density-responsive transcriptional regulators. J. Bacteriol. 1994, 176, 269-275. [CrossRef] [PubMed]

3. Miller, M.B.; Bassler, B.L. Quorum sensing in bacteria. Annu. Rev. Microbiol. 2001, 55, 165-199. [CrossRef] [PubMed]

4. Rutherford, S.T.; Bassler, B.L. Bacterial quorum sensing: Its role in virulence and possibilities for its control. Cold Spring Harb. Perspect. Med. 2012, 2, a012427. [CrossRef]

5. Dong, Y.H.; Zhang, L.H. Quorum sensing and quorum-quenching enzymes. J. Microbiol. 2005, 43, 101-109. [PubMed]

6. LaSarre, B.; Federle, M.J. Exploiting Quorum Sensing to Confuse Bacterial Pathogens. Microbiol. Mol. Biol. Rev. $2013,77,73-111$. [CrossRef]

7. Uroz, S.; Dessaux, Y.; Oger, P. Quorum sensing and quorum quenching: The yin and yang of bacterial communication. ChemBioChem 2009, 10, 205-216. [CrossRef]

8. Uroz, S.; Chhabra, S.R.; Cámara, M.; Williams, P.; Oger, P.; Dessaux, Y. N-acylhomoserine lactone quorum-sensing molecules are modified and degraded by Rhodococcus erythropolis W2 by both amidolytic and novel oxidoreductase activities. Microbiology 2005, 151, 3313-3322. [CrossRef]

9. Chen, F.; Gao, Y.; Chen, X.; Yu, Z.; Li, X. Quorum quenching enzymes and their application in degrading signal molecules to block quorum sensing-dependent infection. Int. J. Mol. Sci. 2013, 14, 17477-17500. [CrossRef] [PubMed]

10. Piewngam, P.; Chiou, J.; Chatterjee, P.; Otto, M. Alternative approaches to treat bacterial infections: Targeting quorum-sensing. Expert Rev. Anti Infect. Ther. 2020, 18, 499-510. [CrossRef] [PubMed]

11. Bzdrenga, J.; Daude, D.; Remy, B.; Jacquet, P.; Plener, L.; Elias, M.; Chabriere, E. Biotechnological applications of quorum quenching enzymes. Chem. Biol. Interact. 2017, 267, 104-115. [CrossRef]

12. Soler, A.; Arregui, L.; Arroyo, M.; Mendoza, J.A.; Muras, A.; Alvarez, C.; Garcia-Vera, C.; Marquina, D.; Santos, A.; Serrano, S. Quorum Sensing versus Quenching Bacterial Isolates Obtained from MBR Plants Treating Leachates from Municipal Solid Waste. Int. J. Environ. Res. Public Health 2018, 15, 1019. [CrossRef] [PubMed]

13. Köse-Mutlu, B.; Ergön-Can, T.; Koyuncu, I.; Lee, C.-H. Quorum quenching for effective control of biofouling in membrane bioreactor: A comprehensive review of approaches, applications, and challenges. Environ. Eng. Res. 2019, 24, 543-558. [CrossRef]

14. Geske, G.D.; O’Neill, J.C.; Blackwell, H.E. Expanding dialogues: From natural autoinducers to non-natural analogues that modulate quorum sensing in Gram-negative bacteria. Chem. Soc. Rev. 2008, 37, 1432-1447. [CrossRef] [PubMed]

15. Fetzner, S. Quorum quenching enzymes. J. Biotechnol. 2015, 201, 2-14. [CrossRef] [PubMed]

16. Duggleby, H.J.; Tolley, S.P.; Hill, C.P.; Dodson, E.J.; Dodson, G.; Moody, P.C. Penicillin acylase has a single-amino-acid catalytic centre. Nature 1995, 373, 264-268. [CrossRef]

17. Oinonen, C.; Rouvinen, J. Structural comparison of Ntn-hydrolases. Protein Sci. 2000, 9, 2329-2337. [CrossRef]

18. Sudhakaran, V.K.; Deshpande, B.S.; Ambedkar, S.S.; Shewale, J.G. Molecular aspects of penicillin and cephalosporin acylases. Process. Biochem. 1992, 27, 131-143. [CrossRef]

19. Sunder, A.V.; Utari, P.D.; Ramasamy, S.; van Merkerk, R.; Quax, W.; Pundle, A. Penicillin V acylases from gram-negative bacteria degrade N-acylhomoserine lactones and attenuate virulence in Pseudomonas aeruginosa. Appl. Microbiol. Biotechnol. 2017, 101, 2383-2395. [CrossRef] [PubMed]

20. Utari, P.D.; Vogel, J.; Quax, W.J. Deciphering Physiological Functions of AHL Quorum Quenching Acylases. Front. Microbiol. 2017, 8, 1123. [CrossRef] [PubMed]

21. Bruggink, A.; Roos, E.C.; de Vroom, E. Penicillin acylase in the industrial production of beta-lactam antibiotics. Org. Process. Res. Dev. 1998, 2, 128-133. [CrossRef]

22. Arroyo, M.; de la Mata, I.; Acebal, C.; Castillón, M.P. Biotechnological applications of penicillin acylases: State-of-the-art. Appl. Microbiol. Biotechnol. 2003, 60, 507-514. [CrossRef]

23. Velasco-Bucheli, R.; del Cerro, C.; Hormigo, D.; Acebal, C.; Arroyo, M.; García, J.L.; de la Mata, I. Draft genome sequence of Actinoplanes utahensis NRRL 12052, a microorganism involved in industrial production of pharmaceutical intermediates. Genome Announc. 2015, 3, e01411-e01414. [CrossRef]

24. Inokoshi, J.; Takeshima, H.; Ikeda, H.; Omura, S. Cloning and sequencing of the aculeacin A acylase-encoding gene from Actinoplanes utahensis and expression in Streptomyces lividans. Gene 1992, 119, 29-35. [CrossRef]

25. Medema, M.H.; Blin, K.; Cimermancic, P.; de Jager, V.; Zakrzewski, P.; Fischbach, M.A.; Weber, T.; Takano, E.; Breitling, R. antiSMASH: Rapid identification, annotation and analysis of secondary metabolite biosynthesis gene clusters in bacterial and fungal genome sequences. Nucleic Acids Res. 2011, 39, W339-W346. [CrossRef] [PubMed]

26. Petersen, T.N.; Brunak, S.; von Heijne, G.; Nielsen, H. SignalP 4.0: Discriminating signal peptides from transmembrane regions. Nat. Methods 2011, 8, 785-786. [CrossRef]

27. Gasteiger, E.; Hoogland, C.; Gattiker, A.; Duvaud, S.E.; Wilkins, M.R.; Appel, R.D.; Bairoch, A. Protein identification and analysis tools on the ExPASy server. In The Proteomics Protocols Handbook; Walker, J.M., Ed.; Humana Press: Totowa, NJ, USA, 2005; pp. 571-607. 
28. Torres-Bacete, J.; Hormigo, D.; Stuart, M.; Arroyo, M.; Torres, P.; Castillón, M.P.; Acebal, C.; García, J.L.; de la Mata, I. Newly discovered penicillin acylase activity of aculeacin A acylase from Actinoplanes utahensis. Appl. Environ. Microbiol. 2007, 73, 5378-5381. [CrossRef] [PubMed]

29. Torres-Bacete, J.; Hormigo, D.; Torres-Gúzman, R.; Arroyo, M.; Castillón, M.P.; García, J.L.; Acebal, C.; de la Mata, I. Overexpression of penicillin V acylase from Streptomyces lavendulae and elucidation of its catalytic residues. Appl. Environ. Microbiol. 2015, 81, 1225-1233. [CrossRef]

30. Zhang, D.; Koreishi, M.; Imanaka, H.; Imamura, K.; Nakanishi, K. Cloning and characterization of penicillin V acylase from Streptomyces mobaraensis. J. Biotechnol. 2007, 128, 788-800. [CrossRef] [PubMed]

31. Park, S.Y.; Kang, H.O.; Jang, H.S.; Lee, J.K.; Koo, B.T.; Yum, D.Y. Identification of extracellular N-acylhomoserine lactone acylase from a Streptomyces sp. and its application to quorum quenching. Appl. Environ. Microbiol. 2005, 71, 2632-2641. [CrossRef] [PubMed]

32. Ueda, S.; Shibata, T.; Ito, K.; Oohata, N.; Yamashita, M.; Hino, M.; Yamada, M.; Isogai, Y.; Hashimoto, S. Cloning and expression of the FR901379 acylase gene from Streptomyces sp. no. 6907. J. Antibiot. 2011, 64, 169-175. [CrossRef] [PubMed]

33. Papadopoulos, J.S.; Agarwala, R. COBALT: Constraint-based alignment tool for multiple protein sequences. Bioinformatics 2007, 23, 1073-1079. [CrossRef] [PubMed]

34. Edelhoch, H. Spectroscopic determination of tryptophan and tyrosine in proteins. Biochemistry 1967, 6, 1948-1954. [CrossRef] [PubMed]

35. Shannon, G.; Marples, C.R.; Toofanny, R.D.; Williams, P.M. Evolutionary drivers of protein shape. Sci. Rep. 2019, 9, 11873. [CrossRef] [PubMed]

36. Hormigo, D.; Lopez-Conejo, M.T.; Serrano-Aguirre, L.; García-Martín, A.; Saborido, A.; de la Mata, I.; Arroyo, M. Kinetically controlled acylation of 6-APA catalyzed by penicillin acylase from Streptomyces lavendulae: Effect of reaction conditions in the enzymatic synthesis of penicillin V. Biocatal. Biotransform. 2020, 38, 253-262. [CrossRef]

37. Geske, G.D.; Mattmann, M.E.; Blackwell, H.E. Evaluation of a focused library of N-aryl L-homoserine lactones reveals a new set of potent quorum sensing modulators. Bioorg. Med. Chem. Lett. 2008, 18, 5978-5981. [CrossRef]

38. García-Hidalgo, J.; Hormigo, D.; Prieto, M.; Arroyo, M.; de la Mata, I. Extracellular production of Streptomyces exfoliatus poly(3hydroxybutyrate) depolymerase in Rhodococcus sp. T104: Determination of optimal biocatalyst conditions. Appl. Microbiol. Biotechnol. 2012, 93, 1975-1988. [CrossRef]

39. García-Hidalgo, J.; Hormigo, D.; Arroyo, M.; de la Mata, I. Novel extracellular PHB depolymerase from Streptomyces ascomycinicus: PHB copolymers degradation in acidic conditions. PLoS ONE 2013, 8, e71699. [CrossRef]

40. Torres, R.; de la Mata, I.; Castillón, M.P.; Arroyo, M.; Torres, J.; Acebal, C. Purification and characterization of penicillin V acylase from Streptomyces lavendulae. In Progress in Biotechnology; Ballesteros, A., Plou, F.J., Iborra, J.L., Halling, P.J., Eds.; Elsevier: Cordoba, Spain, 1998; pp. 719-724.

41. Koch, G.; Nadal-Jimenez, P.; Cool, R.H.; Quax, W.J. Deinococcus radiodurans can interfere with quorum sensing by producing an AHL-acylase and an AHL-lactonase. FEMS Microbiol. Lett. 2014, 356, 62-70. [CrossRef]

42. Chen, C.-N.; Chen, C.-J.; Liao, C.-T.; Lee, C.-Y. A probable aculeacin A acylase from the Ralstonia solanacearum GMI1000 is $\mathrm{N}$-acyl-homoserine lactone acylase with quorum-quenching activity. BMC Microbiol. 2009, 9, 89-99. [CrossRef] [PubMed]

43. Lin, Y.-H.; Xu, J.-L.; Hu, J.; Wang, L.-H.; Ong, S.L.; Leadbetter, J.R.; Zhang, L.-H. Acyl-homoserine lactone acylase from Ralstonia strain XJ12B represents a novel and potent class of quorum-quenching enzymes. Mol. Microbiol. 2003, 47, 849-860. [CrossRef] [PubMed]

44. Reina, J.C.; Romero, M.; Salto, R.; Camara, M.; Llamas, I. AhaP, A Quorum Quenching Acylase from Psychrobacter sp. M9-54-1 That Attenuates Pseudomonas aeruginosa and Vibrio coralliilyticus Virulence. Mar. Drugs 2021, 19, 16. [CrossRef]

45. Kusada, H.; Tamaki, H.; Kamagata, Y.; Hanada, S.; Kimura, N. A Novel Quorum-Quenching N-Acylhomoserine Lactone Acylase from Acidovorax sp Strain MR-S7 Mediates Antibiotic Resistance. Appl. Environ. Microbiol. 2017, 83, e00080-17. [CrossRef] [PubMed]

46. Shepherd, R.W.; Lindow, S.E. Two dissimilar N-acyl-homoserine lactone acylases of Pseudomonas syringae influence colony and biofilm morphology. Appl. Environ. Microbiol. 2009, 75, 45-53. [CrossRef]

47. Bokhove, M.; Jimenez, P.N.; Quax, W.J.; Dijkstra, B.W. The quorum-quenching N-acyl homoserine lactone acylase PvdQ is an Ntn-hydrolase with an unusual substrate-binding pocket. Proc. Natl. Acad. Sci. USA 2010, 107, 686-691. [CrossRef] [PubMed]

48. Morohoshi, T.; Nakazawa, S.; Ebata, A.; Kato, N.; Ikeda, T. Identification and characterization of N-acylhomoserine lactone-acylase from the fish intestinal Shewanella sp. strain MIB015. Biosci. Biotechnol. Biochem. 2008, 72, 1887-1893. [CrossRef]

49. Avinash, V.S.; Pundle, A.V.; Ramasamy, S.; Suresh, C.G. Penicillin acylases revisited: Importance beyond their industrial utility. Crit. Rev. Biotechnol. 2016, 36, 303-316. [CrossRef]

50. Philem, P.D.; Yadav, Y.; Vellore Sunder, A.; Ghosh, D.; Prabhune, A.; Ramasamy, S. Structural and enzymatic analysis of a dimeric cholylglycine hydrolase like acylase active on N-acyl homoserine lactones. Biochimie 2020, 177, 108-116. [CrossRef]

51. Liu, N.; Yu, M.; Zhao, Y.; Cheng, J.; An, K.; Zhang, X.H. PfmA, a novel quorum-quenching N-acylhomoserine lactone acylase from Pseudoalteromonas flavipulchra. Microbiology 2017, 163, 1389-1398. [CrossRef]

52. Mukherji, R.; Varshney, N.K.; Panigrahi, P.; Suresh, C.G.; Prabhune, A. A new role for penicillin acylases: Degradation of acyl homoserine lactone quorum sensing signals by Kluyvera citrophila penicillin G acylase. Enzym. Microb. Technol. 2014, 56, 1-7. [CrossRef] 
53. Velasco-Bucheli, R.; Hormigo, D.; Fernández-Lucas, J.; Torres-Ayuso, P.; Alfaro-Ureña, Y.; Saborido, A.I.; Serrano-Aguirre, L.; García, J.L.; Ramón, F.; Acebal, C.; et al. Penicillin Acylase from Streptomyces lavendulae and Aculeacin A Acylase from Actinoplanes utahensis: Two Versatile Enzymes as Useful Tools for Quorum Quenching Processes. Catalysts 2020, 10, 730. [CrossRef]

54. Torres-Guzmán, R.; de la Mata, I.; Torres-Bacete, J.; Arroyo, M.; Castillón, M.P.; Acebal, C. Substrate specificity of penicillin acylase from Streptomyces lavendulae. Biochem. Biophys. Res. Commun. 2002, 291, 593-597. [CrossRef] [PubMed]

55. Wahjudi, M.; Papaioannou, E.; Hendrawati, O.; van Assen, A.H.G.; van Merkerk, R.; Cool, R.H.; Poelarends, G.J.; Quax, W.J. PA0305 of Pseudomonas aeruginosa is a quorum quenching acylhomoserine lactone acylase belonging to the Ntn hydrolase superfamily. Microbiology 2011, 157, 2042-2055. [CrossRef] [PubMed]

56. Koch, G.; Nadal-Jimenez, P.; Reis, C.R.; Muntendam, R.; Bokhove, M.; Melillo, E.; Dijkstra, B.W.; Cool, R.H.; Quax, W.J. Reducing virulence of the human pathogen Burkholderia by altering the substrate specificity of the quorum-quenching acylase PvdQ. Proc. Natl. Acad. Sci. USA 2014, 111, 1568-1573. [CrossRef]

57. Koreishi, M.; Tani, K.; Ise, Y.; Imanaka, H.; Imamura, K.; Nakanishi, K. Enzymatic synthesis of b-lactam antibiotics and N-fattyacylated amino compounds by the acyl-transfer reaction catalyzed by penicillin V acylase from Streptomyces mobaraensis. Biosci. Biotechnol. Biochem. 2007, 71, 1582-1586. [CrossRef] [PubMed]

58. Càmara, M.; Daykin, M.; Chhabra, S.R. 6.12 Detection, purification, and synthesis of N-acylhomoserine lactone quorum sensing signal molecules. Methods Microbiol. 1998, 27, 319-330. [CrossRef]

59. McInnis, C.E.; Blackwell, H.E. Non-native N-aroyl L-homoserine lactones are potent modulators of the quorum sensing receptor RpaR in Rhodopseudomonas palustris. Chembiochem. Eur. J. Chem. Biol. 2014, 15, 87-93. [CrossRef]

60. Syrpas, M.; Ruysbergh, E.; Stevens, C.V.; De Kimpe, N.; Mangelinckx, S. Synthesis and biological evaluation of novel N- $\alpha-$ haloacylated homoserine lactones as quorum sensing modulators. Beilstein J. Org. Chem. 2014, 10, 2539-2549. [CrossRef]

61. Vazquez-Martinez, J.; Nieto-Alvarez, E.; Ramirez-Chavez, E.; Molina-Torres, J. Enzymatic Method for N-Acyl Homoserine Lactones Synthesis Using Immobilized Candida antarctica Lipase. Catal. Lett. 2018, 148, 62-67. [CrossRef]

62. Burk, M.J.; Van Dien, S. Biotechnology for Chemical Production: Challenges and Opportunities. Trends Biotechnol. 2016, 34, 187-190. [CrossRef] [PubMed]

63. Alcántara, A.R. Biocatalysis and Pharmaceuticals: A Smart Tool for Sustainable Development. Catalysts 2019, 9, 792. [CrossRef]

64. Hanahan, D. Studies on transformation of Escherichia coli with plasmid. J. Mol. Biol. 1983, 166, 557-580. [CrossRef]

65. Kieser, T.; Bibb, M.J.; Buttner, M.J.; Chater, K.F.; Hopwood, D.A. Practical Streptomyces Genetics; The John Innes Foundation: Norwich, UK, 2000.

66. Sambrook, J.; Russel, D.W. Molecular Cloning: A Laboratory Manual, 3rd ed.; Cold Spring Harbor: New York, NY, USA, 2001.

67. McClean, K.H.; Winson, M.K.; Fish, L.; Taylor, A.; Chhabra, S.R.; Camara, M.; Daykin, M.; Lamb, J.H.; Swift, S.; Bycroft, B.W.; et al. Quorum sensing and Chromobacterium violaceum: Exploitation of violacein production and inhibition for the detection of $\mathrm{N}$-acylhomoserine lactones. Microbiology 1997, 143, 3703-3711. [CrossRef]

68. Quirós, L.M.; Aguirrezabalaga, I.; Olano, C.; Méndez, C.; Salas, J.A. Two glycosyltransferases and a glycosidase are involved in oleandomycin modification during its biosynthesis by Streptomyces antibioticus. Mol. Microbiol. 1998, 28, 1177-1185. [CrossRef]

69. Chiba, K.; Hoshino, Y.; Ishino, K.; Kogure, T.; Mikami, Y.; Uehara, Y.; Ishikawa, J. Construction of a pair of practical NocardiaEscherichia coli shuttle vectors. Jpn. J. Infect. Dis. 2007, 60, 45-47.

70. Sanger, F.; Nicklen, S.; Coulson, A.R. DNA sequencing with chain-terminating inhibitors. Proc. Natl. Acad. Sci. USA 1977, 74, 5463-5467. [CrossRef]

71. Takeshima, H.; Inokoshi, J.; Takada, Y.; Tanaka, H.; Omura, S. A deacylation enzyme for aculeacin A, a neutral lipopeptide antibiotic, from Actinoplanes utahensis: Purification and characterization. J. Biochem. 1989, 105, 606-610. [CrossRef] [PubMed]

72. Bradford, M.M. A rapid and sensitive method for quantification of microgram quantities of protein utilizing the principle of protein-dye binding. Anal. Biochem. 1976, 72, 248-252. [CrossRef]

73. Speicher, K.D.; Gorman, N.; Speicher, D.W. N-terminal sequence analysis of proteins and peptides. Curr. Protoc. Protein Sci. 2009, 57, 11.10.11-11.10.31. [CrossRef]

74. Böhm, G.; Muhr, R.; Jaenicke, R. Quantitative analysis of protein far-UV circular dicroism spectra by neural networks. Protein Eng. 1992, 5, 191-195. [CrossRef]

75. Ludtke, S.J.; Baldwin, P.R.; Chiu, W. EMAN: Semiautomated Software for High-Resolution Single-Particle Reconstructions. J. Struct. Biol. 1999, 128, 82-97. [CrossRef] [PubMed]

76. Balasingham, K.; Warburton, D.; Dunnill, P.; Lilly, M.D. The isolation and kinetics of penicillin amidase from Escherichia coli. Biochim. Biophys. Acta 1972, 276, 250-256. [CrossRef] 